\title{
Defunctionalized Lobeline Analogues: Structure-Activity of Novel Ligands for the Vesicular Monoamine Transporter
}

\author{
Guangrong Zheng, Linda P. Dwoskin, Agripina G. Deaciuc, Seth D. Norrholm, and Peter A. \\ Crooks* \\ College of Pharmacy, University of Kentucky, Lexington, Kentucky 40536-0082
}

\begin{abstract}
(-)-Lobeline $(2 R, 6 S, 10 S ; \mathbf{1 a})$, an antagonist at nicotinic acetylcholine receptors (nAChRs), inhibits the neurochemical and behavioral effects of methamphetamine and inhibits dopamine transporter (DAT) and vesicular monoamine transporter (VMAT2) function. VMAT2 is a target for the development of treatments for methamphetamine abuse. Structural modification of lobeline affords the defunctionalized analogues meso-transdiene (MTD) and lobelane, which have high potency and selectivity for VMAT2. To establish the structure-activity relationships within this novel class of VMAT2 ligands, specific stereochemical forms of MTD, lobelane, and other structurally related analogues have been synthesized. These compounds have been evaluated for inhibition of $\left[{ }^{3} \mathrm{H}\right]$ nicotine $\left(\left[{ }^{3} \mathrm{H}\right] \mathrm{NIC}\right)$ binding $(\mathrm{a} 4 \beta 2 * \mathrm{nAChR}),\left[{ }^{3} \mathrm{H}\right]$ methyllycaconitine $\left(\left[{ }^{3} \mathrm{H}\right] \mathrm{MLA}\right)$ binding $\left(a 7^{*} \mathrm{nAChR}\right)$, and $\left[{ }^{3} \mathrm{H}\right]$ dihydrotetrabenazine $\left(\left[{ }^{3} \mathrm{H}\right] \mathrm{DTBZ}\right)$ binding (VMAT2). Generally, all of these analogues had lower affinities at a $4 \beta 2 *$ and $a 7 *$ nAChRs compared to lobeline, thereby increasing selectivity for VMAT2. The following structural modifications resulted in only modest changes in affinity for VMAT2, affording analogues that were less potent than the lead compound, lobelane: (1) altering the stereochemistry at the C-2 and C-6 positions of the piperidino ring, (2) varying unsaturation in the piperidino C-2 and C- 6 substituents, (3) introducing unsaturation into the piperidine ring, (4) ring-opening or eliminating the piperidine ring, and (5) removing the piperidino $N$-methyl group. Furthermore, incorporating a quaternary ammonium group into defunctionalized lobeline molecules in the cis-series resulted in significant loss of affinity for VMAT2, whereas only a modest change in affinity was obtained in the transseries. The most potent $\left(K_{\mathrm{i}}=630 \mathrm{nM}\right)$ and VMAT2-selective compound evaluated was the $N$ methyl-2,6-cis-bis(naphthaleneethyl)piperidine analogue $28 \mathbf{b}$ (1-NAP-lobelane), in which the phenyl groups of lobelane were replaced with 1-naphthyl moieties. Thus, initial structure-activity relationship studies reveal that the most promising structural changes to the lobeline molecule that lead to enhancement of VMAT2 affinity and selectivity are defunctionalization, affording lobelane and MTD, and replacement of the phenyl rings of lobelane with other aromatic moieties that have a $\pi$-extended structure.
\end{abstract}

\section{Introduction}

Psychostimulant-induced behavioral activation and reinforcement are mediated, at least in part, via interaction with neurotransmitter transporters, which regulate synaptic dopamine (DA) concentrations. ${ }^{1,2}$ Recent studies have demonstrated that psychostimulants alter vesicular monoamine transporter (VMAT2) function. ${ }^{3}$ Methamphetamine decreases VMAT2 function ${ }^{4,5}$ and is also a substrate for the DA transporter (DAT). ${ }^{6,7}$ VMAT2

\footnotetext{
(C) 2005 American Chemical Society

*To whom correspondences should be addressed. Phone: 859-257-1718. Fax: 859-257-7585. pcrooks@email.uky.edu. Supporting Information Available: Elemental analyses data. This information is available free of charge via the Internet at http:// pubs.acs.org.
} 
heterologous knockout mice exhibit reduced amphetamine conditioned reward, ${ }^{8}$ enhanced amphetamine locomotion, ${ }^{8}$ and enhanced sensitivity to cocaine and amphetamine, ${ }^{9}$ indicating that VMAT2 plays an important role in mediating the behavioral effects of psychostimulants. These results support the idea that VMAT2 should be considered as a target for the development of pharmacotherapies to treat psychostimulant abuse. Other evidence supporting the role of VMAT2 in psychostimulant pharmacology is the finding that benzoquinolizine derivatives, such as tetrabenazine, have high affinity for VMAT2, decrease locomotor activity and aggressiveness in monkeys, and, moreover, depress methamphetamine-induced hyperactivity in rats and mice. ${ }^{13}$

(-)-Lobeline (2R,6S,10S; 1a) (Figure 1), a weakly basic lipophilic alkaloid from Lobelia inflata, interacts with VMAT2 and DAT via a novel mechanism of action. ${ }^{14}$ Lobeline potently inhibits $\left[{ }^{3} \mathrm{H}\right]$ dihydroxytetrabenazine $\left(\left[{ }^{3} \mathrm{H}\right] \mathrm{DTBZ}\right)$ binding to VMAT2 with an $\mathrm{IC}_{50}$ of $0.90 \mu \mathrm{M}$ and inhibits $\left[{ }^{3} \mathrm{H}\right] \mathrm{DA}$ uptake into rat striatal vesicle preparations with an $\mathrm{IC}_{50}$ of $0.88 \mu \mathrm{M} .{ }^{15,16}$ Furthermore, lobeline also inhibits $\left(\mathrm{IC}_{50}=80 \mu \mathrm{M}\right)\left[{ }^{3} \mathrm{H}\right] \mathrm{DA}$ uptake into rat striatal synaptosomes via DAT, but with 100 -fold lower affinity. ${ }^{15}$ Importantly, lobeline has been shown to inhibit both the neurochemical and behavioral effects of amphetamine in rodents. ${ }^{17-19}$ Specifically, methamphetamine-evoked DA release from rat striatal slices is inhibited by lobeline. ${ }^{17}$ Furthermore, lobeline attenuates $d$-amphetamine-, methamphetamine-, and nicotine-induced hyperactivity in rodents. ${ }^{17,20}$ Importantly, lobeline is not self-administered but decreases methamphetamine self-administration in rats. ${ }^{18,19}$ The lobeline-induced decrease in methamphetamine self-administration was not surmounted by increasing unit doses of methamphetamine. ${ }^{18,19}$ Taken together, these results suggest that lobeline lacks abuse liability, while decreasing the stimulant and rewarding effects of methamphetamine via a noncompetitive interaction with VMAT2. Consistent with the observation that lobeline is not self-administered, ${ }^{19}$ lobeline does not evoke DA release but stimulates dihydroxyphenylacetic acid overflow, ${ }^{15}$ which likely results from alterations in presynaptic DA storage via an interaction with VMAT2. ${ }^{14}$ Furthermore, the observation that lobeline inhibits $d$-amphetamine- and methamphetamine-evoked DA release from superfused rat striatal slices ${ }^{17}$ is consistent with its inhibition of methamphetamine selfadministration. ${ }^{18}$ Thus, VMAT2 appears to be a novel target for development of therapeutic candidates to treat methamphetamine abuse.

In addition to its activity at VMAT2, lobeline acts as an antagonist at nicotinic acetylcholine receptors (nAChRs). ${ }^{21}$ Lobeline inhibits nicotine-evoked $\left[{ }^{3} \mathrm{H}\right] \mathrm{DA}$ overflow from rat striatal slices with an $\mathrm{IC}_{50}$ of $1 \mu \mathrm{M}$, suggesting that lobeline acts as an antagonist at a $6 \beta 2 \beta 3^{*}$ nAChRs that mediate DA release. ${ }^{21}$ Lobeline also inhibits nicotine-evoked ${ }^{86} \mathrm{Rb}^{+}$efflux from rat thalamic synaptosomes with an $\mathrm{IC}_{50}$ of $0.7 \mu \mathrm{M}$ and inhibits $\left[{ }^{3} \mathrm{H}\right]$ nicotine $\left(\left[{ }^{3} \mathrm{H}\right] \mathrm{NIC}\right)$ binding to rat striatal membranes with a $K_{\mathrm{i}}$ of $4.7 \mathrm{nM}$, indicating that lobeline is also an antagonist at a $4 \beta 2 *$ nAChRs. ${ }^{21}$ Moreover, lobeline also inhibits $\left[{ }^{3} \mathrm{H}\right]$ methyllycaconitine ( $\left[{ }^{3} \mathrm{H}\right] \mathrm{MLA}$ ) binding to rat brain membranes with a $K_{\mathrm{i}}$ of $6.26 \mu \mathrm{M}$, indicating an interaction with the $a 7^{*} \mathrm{nAChR}$ subtype. ${ }^{22}$ Lobeline has also been reported to be an antagonist at human a $7 *$ nAChRs expressed in Xenopus oocytes with an $\mathrm{IC}_{50}$ of $8.5 \mu \mathrm{M} .{ }^{23}$

Due to the multiple pharmacological actions of lobeline, it is important to examine structural analogues of lobeline to begin to define the receptor pharmacophores and develop compounds with enhanced selectivity. Our preliminary studies ${ }^{22,24}$ show that structural changes to the lobeline molecule, such as removal of one or both of the oxygen functionalities, result in a decrease in $\mathrm{a} 4 \beta 2 * \mathrm{nAChR}$ affinity, which is consistent with the findings of others. ${ }^{25}$ Thus, it is possible that analogues of lobeline can be developed with selectivity for VMAT2. Drug discovery selectively targeting VMAT2 may provide a unique opportunity to further probe the underlying neurochemical mechanisms responsible for psychostimulant abuse and may provide a novel approach for its treatment. To date, there 
are very few VMAT2 ligands reported in the literature; these include low affinity ligands, such as 3-amino-2-phenylpropene derivatives (2), ${ }^{26}$ and high affinity tetrabenazine analogues, such as dihydrotetrabenazine (3) and Ro4-1284 (4) ${ }^{27,28}$ (Figure 1). Thus, lobeline analogues with selectivity for VMAT2 provide a novel structural class of VMAT2 ligand as potential leads for therapeutic development.

Selective targeting of VMAT2 by systematic structural modification of lobeline provided two non-oxygen containing lobeline analogues: $\mathrm{N}$-methyl-2,6-bis( cisphenylethenyl)piperidine (meso-transdiene, MTD, 5a) and $N$-methyl-2,6-bis(cisphenylethyl)piperidine (lobelane, 6a) (Scheme 1). The latter two analogues showed good affinity for VMAT2 and DAT, with negligible affinity for $a 4 \beta 2^{*}$ and $a 7^{*}$ nAChRs. ${ }^{22}$ Of note, both $5 \mathbf{a}$ and $6 \mathbf{a}$ are optically inactive meso-compounds. These interesting results prompted us to carry out a more detailed investigation of the structure-activity of the various isomeric forms of $\mathbf{5 a}$ and $\mathbf{6 a}$, as well as structurally related defunctionalized analogues, to identify selective ligands for VMAT2 that have potential as therapeutic interventions in psychostimulant abuse.

\section{Chemistry}

The synthetic routes to the defunctionalized analogues $\mathbf{5 a - 5 c}, \mathbf{6 a - 6 c}$, and 13a-13d all emanate from lobeline (1a) and are illustrated in Scheme 1. C-2 epimerization of lobeline (1a) in $\mathrm{K}_{2} \mathrm{CO}_{3} /$ methanol for $48 \mathrm{~h}$ at room temperature afforded an equal mixture of the two C-2 epimers, $\mathbf{1 a}$ and $\mathbf{1 b},{ }^{29,30}$ which were transformed into compound $\mathbf{7}$ via reduction with $\mathrm{NaBH}_{4}$ in absolute ethanol. Utilizing previously described dehydration methodologies, ${ }^{25,31}$ compound 7 was treated with $85 \%$ phosphoric acid to yield a mixture of the cis-and transdistyryl compounds $\mathbf{5} \mathbf{a}^{31}$ (MTD) and $\mathbf{5 b}^{31}$ ((-)-TTD), which were obtained in their pure isomeric forms via silica gel column chromatographic separation. Catalytic hydrogenation of $\mathbf{5 a}$ afforded lobelane $(\mathbf{6 a}),{ }^{25,32}$ and similar treatment of $\mathbf{5 b}$ afforded (-)-2S,6S trans-lobelane $[(-)$-trans-lobelane, $\mathbf{6 b}]$. The unsaturated lobeline analogue, $\mathbf{8}$, which was prepared by Clemmensen reduction of lobeline (1a) ${ }^{25}$ was converted into a mixture of the C-6 epimers of 9 through Jones oxidation, followed by treatment with $\mathrm{K}_{2} \mathrm{CO}_{3} /$ methanol. The mixture of the epimers of 9 was reduced with $\mathrm{NaBH}_{4} / \mathrm{EtOH}$ to afford $\mathbf{1 0}$, which was a mixture of the four possible diastereomers. Treatment of this isomeric mixture with $85 \% \mathrm{H}_{3} \mathrm{PO}_{4}$ afforded epimers 5a (MTD) and 5c [(+)-TTD], which were separated by silca gel chromatography. Subsequently, catalytic hydrogenation of $\mathbf{5} \mathbf{c}$ gave $(+)-2 R, 6 R$ trans-lobelane $[(+)$-translobelane, 6c] (Scheme 1a).

Dehydration of $\mathbf{1 a}$ with $85 \% \mathrm{H}_{3} \mathrm{PO}_{4}$, followed by epimerization at C-2, afforded $\mathbf{1 1}$ as a mixture of C-2 epimers. Concomitant reduction of the olefinic bond and the carbonyl group in 11 was achieved by catalytic hydrogenation to afford 12, which was a mixture of all four possible diastereomers. Dehydration of 12 with $\mathrm{H}_{3}-\mathrm{PO}_{4}$ afforded 13a and 13b, which were obtained in isomerically pure form by silica gel chromatography. Compound $\mathbf{1 3 c}$ and $\mathbf{1 3 d}$ were obtained from 9 by utilizing the same procedure for the synthesis of 13a and 13b from 11 (vide supra) (Scheme 1b).

The synthesis of compounds $\mathbf{1 7}$ and $\mathbf{1 9}$ is illustrated in Scheme 2. Compound $\mathbf{1 5}$ was prepared by condensation of 2,6-lutidine with benzaldehyde. ${ }^{32}$ Hydrogenation and then methylation of $\mathbf{1 5}$ afforded the quaternary ammonium compound $\mathbf{1 6},{ }^{32}$ which upon reduction with $\mathrm{NaBH}_{4} / \mathrm{EtOH}$ afforded compound 17. A similar procedure was applied to the synthesis of compound $\mathbf{1 9}$ from $\mathbf{1 5}$. Both $\mathbf{1 7}$ and $\mathbf{1 9}$ can be transformed into lobelane (6a) under $\mathrm{Pd}-\mathrm{C}$ catalytic hydrogenation conditions, which indicates that the $\mathrm{C} 2, \mathrm{C} 6$ stereochemistry in $\mathbf{1 7}$ and $\mathbf{1 9}$ is cis. The COSY NMR spectrum of $\mathbf{1 9}$ showed correlations of H-6 ( $\delta 3.00)$ with H-5 ( $\delta 2.22)$ and H-7 $(\delta 6.21)$ and correlations of H-5 ${ }^{\prime}(\delta 2.04)$ with H-4 
$(\delta 5.82)$ and $\mathrm{H}-5(\delta 2.22)$. Thus, as a result of these data, the structure of 19 was assigned as shown in Scheme 2. Norlobelane (20) (Scheme 2) was prepared by catalytic hydrogenation of compound 15 by utilizing $\mathrm{PtO}_{2}$ as the catalyst. ${ }^{32}$ The preparation of compound 22a, the $\mathrm{N}$-demethylated analogue of MTD (5a), is illustrated in Scheme 3. A mixture of cis- and trans-norlobelanine (21) was prepared. ${ }^{31}$ Utilizing a similar procedure for the preparation of $\mathbf{5 a}$ and $\mathbf{5 b}$ from the mixture of lobeline isomers $\mathbf{1 a}$ and $\mathbf{1 b}$, the meso-compound 22a was prepared from $\mathbf{2 1}$ and obtained in an isomerically pure form; the racemic compound $\mathbf{2 2} \mathbf{b} / \mathbf{c}$ was also isolated from this reaction.

The quaternary ammonium compounds $23 \mathbf{a}, \mathbf{2 3 b}, \mathbf{2 4 a}$, and $\mathbf{2 4 b}$ (Figure 2) were prepared by treatment of $\mathbf{5 a}, \mathbf{5 b}, \mathbf{6 a}$, and $\mathbf{6 b}$, respectively, with excess iodomethane in acetone. Ringopened compounds $\mathbf{2 5} \mathbf{a}$ and $\mathbf{2 5} \mathbf{b}$ (Figure 2) were obtained during the hydrogenation of $\mathbf{5 b}$ to $\mathbf{6 b}$ and of $\mathbf{5 c}$ to $\mathbf{6 c}$, respectively, as byproducts. Acyclic compound $\mathbf{2 6 ^ { 3 3 }}$ and $\mathbf{2 7}^{34}$ (Figure 2) were prepared as previously reported. The nor-1-naphthyl and nor-2-naphthyl compounds 28a and 29a were prepared according to the procedure utilized to prepare norlobelane (20), ${ }^{32}$ except that 1 - or 2-naphthaldehyde was used instead of benzaldehyde (Scheme 4). $\mathrm{N}$ Methylation was then carried out using $\mathrm{NaCNBH}_{3} /\left(\mathrm{CH}_{2} \mathrm{O}\right)_{n}$ to afford the corresponding $\mathrm{N}$ methyl compounds, 28b (1-NAP-lobelane) and 29b (2-NAP-lobelane).

\section{Results and Discussion}

Table 1 shows that lobeline (1a) potently inhibited $\left[{ }^{3} \mathrm{H}\right] \mathrm{NIC}$ binding to rat striatal membranes with a $K_{\mathrm{i}}$ value of $4 \mathrm{nM}$, had low affinity $\left(K_{\mathrm{i}}=6.26 \mu \mathrm{M}\right)$ for a $7^{*} \mathrm{nAChRs}$, and, importantly, inhibited $\left[{ }^{3} \mathrm{H}\right] \mathrm{DTBZ}$ binding at VMAT2 $\left(K_{\mathrm{i}}=2.76 \mu \mathrm{M}\right)$. Partially defunctionalized lobeline analogues, retaining a single oxygen functionality in the molecule, have low affinity at $a 4 \beta 2 * 22,25$ but are equipotent or exhibit higher affinity at $a 7 * .22$ More importantly, these compounds retained affinity at VMAT2, comparable with lobeline. ${ }^{22}$ Further structural modification of the lobeline molecule revealed that the fully deoxygenated, unsaturated meso-compound, MTD (5a), had no affinity at either a $4 \beta 2 *$ or $\mathrm{a} 7 * \mathrm{nAChRs}$ but had comparable but slightly lower affinity $\left(K_{\mathrm{i}}=9.88 \mu \mathrm{M}\right)$ compared with lobeline at VMAT2. Thus, MTD was more selective, but slightly less potent at VMAT2 than lobeline. Reduction of the trans double bonds in MTD afforded lobelane $\left(6 \mathbf{6}, K_{\mathrm{i}}\right.$ value $=$ $0.97 \mu \mathrm{M}$ at VMAT2), which was more selective and 3-fold more potent than lobeline at VMAT2.

The trans analogues of MTD, 5b and $\mathbf{5 c}$, and the trans analogues of lobelane, $\mathbf{6 b}$ and $\mathbf{6 c}$, were synthesized to assess the importance of the C-2 and C-6 stereochemistry of the piperidine ring on VMAT2 affinity and selectivity. Enantiomers $\mathbf{5 b}$ and $\mathbf{5 c}$ had no affinity at either a $4 \beta 2 *$ or a $7 *$ nAChRs. Interestingly, $\mathbf{5 c}$ was equipotent with its meso-isomer, MTD, but $\mathbf{5 b}$ was slightly less potent (2-3-fold) than MTD. Surprisingly, only a small difference in affinity between these two trans enantiomers was observed at VMAT2. These results indicate a surprising lack of stereochemical sensitivity at the ligand recognition site at VMAT2, in that a change in the stereochemistry of the piperidino ring at the $\mathrm{C} 2$ and C6 positions from cis to trans within the MTD series (i.e., from $\mathbf{5 a}$ to $\mathbf{5 b}$ and $\mathbf{5 c}$ ) does not affect interaction with VMAT2. More surprisingly, the observation that there was little difference in affinity for VMAT2 for the trans enantiomers $\mathbf{5 b}$ and $\mathbf{5 c}$ suggests that the specific configuration at $\mathrm{C} 2$ and $\mathrm{C} 6$ in these compounds is not recognized by the VMAT2 binding site. Within the lobelane series of compounds (i.e., $6 \mathbf{a}, \mathbf{6 b}$, and $\mathbf{6 c}$ ), a change of C2, C6 stereochemistry from cis to trans afforded a modest reduction (5-6-fold) in affinity at VMAT2. Again, the trans enantiomers $\mathbf{6 b}$ and $\mathbf{6 c}$ exhibited comparable affinities at VMAT2. Taken together, these data indicate that the VMAT2 binding site does not recognize major stereochemical changes to the MTD and lobelane molecules at the C2 and C6 piperidino ring carbons. 
Reduction of only one double bond in MTD affords enantiomers 13a (cis-lob-7E-ene) and 13c (cis-lob-9E-ene), both of which had no affinity at either a $4 \beta 2 *$ or a $7 *$ nAChRs and, importantly, had significantly higher (4-fold) affinity than MTD at VMAT2, indicating that reduction of just one of the double bonds in MTD results in an increase in affinity and selectivity for VMAT2. Again, it is surprising that there are no differences in affinity between these enantiomers at VMAT2. Similarly, the enantiomers $\mathbf{1 3 b}$ (trans-lob-7E-ene) and 13d (trans-lob-9E-ene) showed no affinity at either a $4 \beta 2 *$ or a $7 *$ nAChRs but interestingly did show very different affinities for VMAT2. Specifically, compound 13b had similar affinity to MTD at VMAT2, whereas 13d exhibited no affinity for VMAT2. These results suggest a somewhat complex structure-activity relationship within these structurally related analogues, in that the VMAT2 recognition site appears to accommodate three translobelene isomers, with different stereochemistry at $\mathrm{C} 2$ and $\mathrm{C} 6$, but does not recognized one specific stereochemical form $\mathbf{1 3 d}$, which has the $2 R, 6 R$ stereochemical configuration.

Increasing conformational rigidity in the piperidine ring by introducing a C-3, C-4 doublebond afforded two racemic cis-analogues, $\mathbf{1 7}$ and 19. Compound 19 is a mixture of enantiomers that are structural analogues of the chirally pure compounds 13a and 13c. The racemic compound $\mathbf{1 7}$ is structurally related to the meso-compound lobelane (6a). As expected, these defunctionalized analogues $[( \pm)-\mathbf{1 7}$ and $( \pm)-\mathbf{1 9}]$ exhibited no affinity at a $4 \beta 2^{*}$ and a $7 *$ nAChRs, were equipotent with compounds 13a and 13c at VMAT2, and exhibited 4-fold lower affinity than lobelane (6a) at VMAT2. Although $\mathbf{1 7}$ and $\mathbf{1 9}$ are racemic, making the structure-activity relationships more difficult to elucidate, it would appear that introduction of unsaturation into the piperidine ring does not markedly affect affinity at VMAT2, since only a modest decrease in affinity is observed in these compounds when compared with the corresponding saturated piperidino ring analogues.

Two conformationally flexible, ring-opened compounds, $\mathbf{2 5} \mathbf{a}$ and $\mathbf{2 5 b}$, were evaluated. Compound 25a and 25b exhibited a 4-5-fold lower affinity compared to lobelane (6a) at VMAT2. Additionally, the two acyclic compounds, 26 and $27\left(K_{\mathrm{i}}=2.37\right.$ and $3.07 \mu \mathrm{M}$, respectively), exhibited lower affinity for VMAT2 compared to lobelane but were comparable to 25a and 25b. Thus, ring-opening or complete removal of the piperidine ring results in only a modest reduction in affinity at VMAT2 compared to lobelane (6a).

The effect of removing the piperidine $N$-methyl substituent of lobelane and its analogues was also investigated. Accordingly, compounds 20, 22a, and 22b/c, which are the corresponding nor-compounds of lobelane $(\mathbf{6 a}), \mathbf{5 a}$, and $\mathbf{5} \mathbf{b} / \mathbf{5} \mathbf{c}$, respectively, were prepared and evaluated. None of these nor-compounds exhibited affinity at either $a 4 \beta 2 *$ or $a 7^{*}$ nAChRs. With respect to VMAT2, removal of the $N$-methyl group did not have a dramatic effect when compared to the corresponding parent $N$-methyl compound. These results suggest that the presence of the $N$-methyl group is not critical for interaction with VMAT2.

1-Methyl-4-phenylpyridinium $\left(\mathrm{MPP}^{+}\right)$, a quaternary ammonium compound, is a well-known ligand for VMAT2. ${ }^{35-38}$ Thus, incorporating a quaternary ammonium group into the above lobeline analogues was considered a structural modification worthy of investigation with regard to enhancing VMAT2 affinity. Four quaternary ammonium analogues of MTD and lobelane, i.e., 23a, 23b, 24a, and $\mathbf{2 4 b}$, were prepared and evaluated. All of these analogues had negligible affinity for $\mathbf{a} 4 \beta 2 * \mathrm{nAChRs}$, although $\mathbf{2 4 a}$ and $\mathbf{2 4 b}$ exhibited low affinity $\left(K_{\mathrm{i}}\right.$ $=2.4-9.6 \mu \mathrm{M}$ ) at $\mathrm{a} 7 * \mathrm{nAChRs}$. Interestingly, compound 23a exhibited no affinity for VMAT2, indicating that $N$-quaternization of MTD eliminates the interaction with this transporter. Similarly, compound 24a, the $N$-quaternized form of lobelane, exhibited a near 20-fold decrease in affinity for VMAT2, compared with lobelane (6a). In the trans-MTD and trans-lobelane series, $\mathrm{N}$-quaternization to afford $\mathbf{2 3 b}$ and $\mathbf{2 4 b}$ afforded only modest changes in affinity for VMAT2, when compared to the corresponding nonquaternized parent 
compounds $5 \mathbf{b}$ and $\mathbf{6 b}$, respectively. In summary, incorporating a quaternary ammonium group into defunctionalized lobeline molecules in the cis-series resulted in significant loss of affinity for VMAT2, whereas only a modest effect was obtained in the trans-series.

Four analogues of lobelane (compounds 28a, 28b, 29a, and 29b), in which the phenyl moieties were replaced with 1-naphthyl or 2-naphthyl moieties to determine the relative contribution of $\pi \angle \pi$ or hydrophobic interactions at the VMAT2 binding site, were prepared. The 1-naph-thyl (28a, 1-NAP-norlobelane, $K_{\mathrm{i}}=4.68 \mu \mathrm{M}$ ) and 2-naphthyl (29a, 2-NAPnorlobelane, $K_{\mathrm{i}}>100 \mu \mathrm{M}$ ) nor-compounds were both less potent than lobelane; however, a dramatic difference in VMAT2 affinity was observed between these meso-analogues. The corresponding $N$-methyl analogues (28b, 1-NAP-lobelane, $K_{\mathrm{i}}=0.63 \mu \mathrm{M} ; \mathbf{2 9 b}, 2-\mathrm{NAP}$ lobelane, $K_{\mathrm{i}}=2.03 \mu \mathrm{M}$ ) exhibited a more modest difference in VMAT2 affinity. More importantly, 1-NAP-lobelane (28b), which incorporates aromatic moieties with a greater $\pi$ surface area, was found to be the most potent and selective lobelane analogue evaluated in this series, suggesting that structural modification of the aromatic moieties of lobelane, and specifically those that increase $\pi<\pi$ interactions and/or hydrophobic interactions at the recognition site of VMAT2, are worth pursuing further.

\section{Summary}

In summary, based upon structural modification of the lobeline molecule, a novel class of VMAT2-selective ligands has been identified. Initial structure-activity relationship studies reveal that the most promising structural changes that enhance VMAT2 affinity and selectivity are defunctionalization, affording lobelane and MTD, and replacement of the phenyl rings with other aromatic moieties that have a $\pi$-extended structure, i.e., a 1-naphthyl moiety.

\section{Experimental Section}

\section{Chemistry}

All purchased reagents were used without further purification. Flash column chromatography was carried out using ICN SilicTech 32-63, 60 Å silica gel. TLC analysis was carried out on EMD Chemicals Inc. glass plates precoated with $250 \mu \mathrm{m}$ silica gel 60 $\mathrm{F}_{254}$. Melting points were determined on a Fisher Scientific melting point apparatus and are uncorrected. NMR spectra were recorded in $\mathrm{CDCl}_{3}$ on a Varian $300 \mathrm{MHz}$ instrument and are reported in ppm relative to TMS as internal standard. Mass spectra were recorded on a JEOL JMS-700T MStation or on a Bruker Autoflex MALDI-TOF MS. GC-mass spectra were recorded on an Agilent 6890 GC incorporating an Agilent 7683 autosampler and an Agilent 5973 MSD. Optical rotation data were obtained on a Perkin-Elmer 241 polarimeter. All of the final amine compounds were converted to their hydrochloride salts with $2 \mathrm{~N} \mathrm{HCl}$ in $\mathrm{Et}_{2} \mathrm{O}$. Elemental analyses were carried out on a COSTECH elemental combustion system and are within $\pm 0.4 \%$ of theory. Compounds $\mathbf{2 0},{ }^{32} \mathbf{2 6},{ }^{33}$ and $\mathbf{2 7} 7^{34}$ were prepared according to previously reported methods.

\section{N-Methyl-2,6-cis-di-(E)-styrylpiperidine (5a) and $\mathrm{N}$-Methyl-2S,6S-trans-di-(E)-} styryl piperidine (5b)-(-)-Lobeline semisulfate salt $(1.85 \mathrm{~g})$ was dissolved in methanol $(100 \mathrm{~mL})$ and treated with excess $\mathrm{K}_{2} \mathrm{CO}_{3}$ for $48 \mathrm{~h}$ at room temperature, concentrated, brought into water, extracted with $\mathrm{CHCl}_{3}$, dried over $\mathrm{Na}_{2} \mathrm{SO}_{4}$, filtered, and concentrated to afford a mixture of $2 R, 6 S$ - and $2 S, 6 S$-lobeline free base in nearly equal ratio (determined by NMR) as a white solid ( $1.35 \mathrm{~g}, 4.00 \mathrm{mmol})$. This product was suspended in absolute ethanol $(40 \mathrm{~mL})$, and $\mathrm{NaBH}_{4}(300 \mathrm{mg}, 8.00 \mathrm{mmol})$ was added at room temperature. The mixture was stirred for $1 \mathrm{~h}$ and then quenched with acetone. The solvents were evaporated under reduced pressure, and the residue was suspended in water $(60 \mathrm{~mL})$ and extracted with $\mathrm{CHCl}_{3}$ 
$(50 \mathrm{~mL} \times 3)$. The combined organic extract was dried $\left(\mathrm{Na}_{2} \mathrm{SO}_{4}\right)$, filtered, and concentrated to give a mixture of lobelanidine and its isomers (7) as a white solid, which was used directly in the next reaction. The crude product 7 was dissolved in $85 \% \mathrm{H}_{3} \mathrm{PO}_{4}(40 \mathrm{~mL})$ and the solution allowed to stir at $60{ }^{\circ} \mathrm{C}$ for $24 \mathrm{~h}$. The reaction mixture was cooled to room temperature, diluted with water $(150 \mathrm{~mL})$, and basified with solid $\mathrm{K}_{2} \mathrm{CO}_{3}$ and then $\mathrm{NaOH}$ $(\mathrm{pH} \sim 10)$. The aqueous solution was then extracted with EtOAc $(80 \mathrm{~mL} \times 3)$. The combined organic extracts were dried $\left(\mathrm{Na}_{2} \mathrm{SO}_{4}\right)$, filtered, and concentrated. The crude product was purified by silica gel column chromatography (10:1 to 1:1 hexanes:EtOAc gradient) to give title compounds $\mathbf{5 a}(390 \mathrm{mg}, 32 \%)$ and $\mathbf{5 b}(341 \mathrm{mg}, 28 \%)$, each as white solids. Compound 5a: mp $149-150{ }^{\circ} \mathrm{C}$ (lit. ${ }^{31} \mathrm{mp} 149-150{ }^{\circ} \mathrm{C}$ ); ${ }^{1} \mathrm{H}$ NMR $\delta 1.42-1.88(\mathrm{~m}, 6 \mathrm{H}), 2.25(\mathrm{~s}, 3 \mathrm{H})$, $2.63(\mathrm{~m}, 2 \mathrm{H}), 6.21(\mathrm{dd}, J=15.9,9.0 \mathrm{~Hz}, 2 \mathrm{H}), 6.51(\mathrm{~d}, J=15.9 \mathrm{~Hz}, 2 \mathrm{H}), 7.19-7.41(\mathrm{~m}, 10 \mathrm{H})$ ppm; ${ }^{13} \mathrm{C}$ NMR $\delta 24.1,33.9,42.6,68.6,126.3,127.5,128.7,130.5,134.0,137.2$ ppm; MS $\mathrm{m} / \mathrm{z} 303\left(\mathrm{M}^{+}\right)$. Anal. $\left(\mathrm{C}_{22} \mathrm{H}_{25} \mathrm{~N} \cdot \mathrm{HCl} \cdot 0.5 \mathrm{H}_{2} \mathrm{O}\right) \mathrm{C}, \mathrm{H}, \mathrm{N}$. Compound 5b: $[\mathrm{a}]^{25} \mathrm{D}-180.2(c 1.0$, $\mathrm{CHCl}_{3}$ ); mp 93-94 ${ }^{\circ} \mathrm{C}$ (lit. $\left.{ }^{31} \mathrm{mp} 96-97{ }^{\circ} \mathrm{C}\right) ;{ }^{1} \mathrm{H}$ NMR $\delta 1.60-1.75(\mathrm{~m}, 4 \mathrm{H}), 1.82-1.97(\mathrm{~m}$, 2H), $2.28(\mathrm{~s}, 3 \mathrm{H}), 3.38(\mathrm{~m}, 2 \mathrm{H}), 6.38(\mathrm{dd}, J=15.9,8.7 \mathrm{~Hz}, 2 \mathrm{H}), 6.52(\mathrm{~d}, J=15.9 \mathrm{~Hz}, 2 \mathrm{H})$, 7.17-7.42 (m, 10H) ppm; ${ }^{13} \mathrm{C}$ NMR $\delta 19.6,32.9,42.0,62.3,126.4,127.5,128.7,130.5$, 131.8, $137.2 \mathrm{ppm}$; MS m/z $303\left(\mathrm{M}^{+}\right)$. Anal. $\left(\mathrm{C}_{22} \mathrm{H}_{25} \mathrm{~N} \cdot \mathrm{HCl} \cdot{ }^{1} /{ }_{3} \mathrm{H}_{2} \mathrm{O}\right) \mathrm{C}, \mathrm{H}, \mathrm{N}$.

N-Methyl-2,6-cis-bis(2-phenethyl)piperidine (6a)—Compound 5a (420 mg, 1.38 $\mathrm{mmol}$ ) was dissolved in methanol $(50 \mathrm{~mL})$ and $10 \% \mathrm{Pd} / \mathrm{C}(40 \mathrm{mg})$ was added. The mixture was hydrogenated on a Parr hydrogenation apparatus ( $45 \mathrm{psi}$ ) for $18 \mathrm{~h}$. The catalyst was removed by filtration through a Celite pad. The filter cake was rinsed with methanol, and the combined organic portions were concentrated under reduced pressure. The resulting residue was purified by silica gel column chromatography $\left(\mathrm{CHCl}_{3}: \mathrm{MeOH} 30: 1\right)$ to afford $\mathbf{6 a}$ (223 $\mathrm{mg}, 53 \%)$ as a white solid: $\mathrm{mp} 171-172{ }^{\circ} \mathrm{C} ;{ }^{1} \mathrm{H}$ NMR $\delta 1.30-1.42(\mathrm{~m}, 4 \mathrm{H}), 1.60-1.85(\mathrm{~m}$, $6 \mathrm{H}), 2.19(\mathrm{~s}, 3 \mathrm{H}), 2.32-2.44(\mathrm{~m}, 2 \mathrm{H}), 2.60-2.77(\mathrm{~m}, 4 \mathrm{H}), 7.12-7.35(\mathrm{~m}, 10 \mathrm{H}) \mathrm{ppm} ;{ }^{13} \mathrm{C}$ NMR $\delta 25.4,27.1,31.0,32.5,36.6,62.7,125.7,128.4,128.5,143.0 \mathrm{ppm} ; \mathrm{MS} \mathrm{m} / z 307$ $\left(\mathrm{M}^{+}\right)$. Anal. $\left(\mathrm{C}_{22} \mathrm{H}_{29} \mathrm{~N} \cdot \mathrm{HCl} \cdot 0.2 \mathrm{H}_{2} \mathrm{O}\right) \mathrm{C}, \mathrm{H}, \mathrm{N}$.

\section{$\mathrm{N}$-Methyl-2S,6S-trans-bis(2-phenethyl)piperidine (6b) and $\mathrm{N}$-Methyl-1,9-} diphenyl-3S-nonanamine (25a)-Compound $6 \mathrm{~b}$ was prepared by utilizing a similar procedure to that described for $\mathbf{6 a}$, except that the starting material was $\mathbf{5 b}(3.0 \mathrm{~g}, 9.90$ $\mathrm{mmol}$ ), to give $1.32 \mathrm{~g} \mathrm{(43 \% )}$ of product as a colorless oil, along with the ring opened product $25 \mathbf{a}(1.35 \mathrm{~g}, 44 \%)$ as a colorless oil. Compound $\mathbf{6 b}$ : $[\mathrm{a}]^{25} \mathrm{D}-35.4\left(c 0.5, \mathrm{CHCl}_{3}\right)$; mp $152-153{ }^{\circ} \mathrm{C}$ ( $\left.\mathrm{HCl} \mathrm{salt}\right) ;{ }^{1} \mathrm{H}$ NMR $\delta 1.37-1.52(\mathrm{~m}, 2 \mathrm{H}), 1.55-1.75(\mathrm{~m}, 6 \mathrm{H}), 1.81-1.95$ $(\mathrm{m}, 2 \mathrm{H}), 2.36(\mathrm{~s}, 3 \mathrm{H}), 2.55-2.67(\mathrm{~m}, 4 \mathrm{H}), 2.67-2.78(\mathrm{~m}, 2 \mathrm{H}), 7.14-7.35(\mathrm{~m}, 10 \mathrm{H}) \mathrm{ppm} ;{ }^{13} \mathrm{C}$ NMR $\delta 20.1,26.6,32.4,33.1,37.9,57.6,125.8,128.4,128.5,142.9 \mathrm{ppm} ; \mathrm{MS} \mathrm{m} / z 307$ $\left(\mathrm{M}^{+}\right)$. Anal. $\left(\mathrm{C}_{22} \mathrm{H}_{29} \mathrm{~N} \cdot \mathrm{HCl} \cdot 0.2 \mathrm{H}_{2} \mathrm{O}\right) \mathrm{C}, \mathrm{H}, \mathrm{N}$. Compound 25a: $[\mathrm{a}]^{25} \mathrm{D}-4.4(c 1.0$, $\left.\mathrm{CHCl}_{3}\right) ;{ }^{1} \mathrm{H}$ NMR $\delta 1.24-1.45(\mathrm{~m}, 6 \mathrm{H}), 1.53-1.71(\mathrm{~m}, 4 \mathrm{H}), 1.94(\mathrm{~m}, 2 \mathrm{H}), 2.52(\mathrm{~s}, 3 \mathrm{H}), 2.59$ (t, $J=7.5 \mathrm{~Hz}, 2 \mathrm{H}), 2.66-2.84(\mathrm{~m}, 3 \mathrm{H}), 6.51$ (brs, $1 \mathrm{H}), 7.09-7.37(\mathrm{~m}, 10 \mathrm{H}) \mathrm{ppm} ;{ }^{13} \mathrm{C}$ NMR $\delta$ 25.5, 29.3, 29.7, 31.3, 31.5, 31.6, 31.8, 33.2, 36.2, 59.1, 125.7, 126.2, 128.3, 128.5 (2C), 128.6, 141.1, 142.8 ppm; MS m/z $309\left(\mathrm{M}^{+}\right)$. Anal. $\left(\mathrm{C}_{22} \mathrm{H}_{31} \mathrm{~N} \cdot \mathrm{HCl}\right) \mathrm{C}, \mathrm{H}, \mathrm{N}$.

N-Methyl-2R,6R-trans-di-(E)-styrylpiperidine (5c)_Jones reagent (prepared by dissolving $26.72 \mathrm{~g}$ of $\mathrm{CrO}_{3}$ in $23 \mathrm{~mL}$ of concentrated $\mathrm{H}_{2} \mathrm{SO}_{4}$, followed by dilution with water to $100 \mathrm{~mL})$ was added dropwise to a solution of compound $\mathbf{8}^{25}(1.22 \mathrm{~g}, 3.80 \mathrm{mmol})$ in acetone $(60 \mathrm{~mL})$ at $0{ }^{\circ} \mathrm{C}$ until an orange-colored reaction mixture was formed. The mixture was stirred for another $30 \mathrm{~min}$, and then methanol was added to quench the reaction. The mixture was then filtered and washed with acetone. The filter cake was dissolved in water $(50 \mathrm{~mL})$ and extracted with $\mathrm{CHCl}_{3}(25 \mathrm{~mL} \times 3)$. The filtrate was concentrated under vacuum and diluted with water $(30 \mathrm{~mL})$. The aqueous solution was extracted with $\mathrm{CHCl}_{3}(25 \mathrm{~mL} \times$ 3 ). The combined organic extracts were dried over anhydrous $\mathrm{Na}_{2} \mathrm{SO}_{4}$, filtered, and 
concentrated to afford a yellow solid. Following a similar procedure previously described for the preparation of compound $\mathbf{5 a}$ and $\mathbf{5 b}$ from LOB sulfate, compound $\mathbf{5} \mathbf{c}$ was prepared to give $3.45 \mathrm{~g}(23 \%)$ as a white solid, along with compound $5 \mathbf{a}(3.22 \mathrm{~g}, 22 \%)$ : [a $]^{25} \mathrm{D} 182.8(\mathrm{c}$ $\left.1.0, \mathrm{CHCl}_{3}\right)$; mp 92-93 ${ }^{\circ} \mathrm{C} ;{ }^{1} \mathrm{H}$ NMR $\delta 1.62-1.75(\mathrm{~m}, 4 \mathrm{H}), 1.80-1.96(\mathrm{~m}, 2 \mathrm{H}), 2.28(\mathrm{~s}, 3 \mathrm{H})$, $3.38(\mathrm{~m}, 2 \mathrm{H}), 6.38(\mathrm{dd}, J=15.9,8.7 \mathrm{~Hz}, 2 \mathrm{H}), 6.52(\mathrm{~d}, J=15.9 \mathrm{~Hz}, 2 \mathrm{H}), 7.20-7.42(\mathrm{~m}, 10 \mathrm{H})$ ppm; ${ }^{13} \mathrm{C}$ NMR $\delta 19.6,32.9,41.9,62.3,126.4,127.5,128.7,130.5,131.7,137.2$ ppm; MS $\mathrm{m} / \mathrm{z} 303\left(\mathrm{M}^{+}\right)$. Anal. $\left(\mathrm{C}_{22} \mathrm{H}_{25} \mathrm{~N} \cdot \mathrm{HCl} \cdot \mathrm{H}_{2} \mathrm{O}\right) \mathrm{C}, \mathrm{H}, \mathrm{N}$.

\section{$N$-Methyl-2R,6R-trans-bis(2-phenethyl)piperidine (6c) and $\mathbf{N}$-Methyl-1,9-} diphenyl-3R-nonanamine (25b) —Compound $\mathbf{6 c}$ was prepared utilizing a similar procedure to that described for $\mathbf{6 a}$, except the starting material was $\mathbf{5 c}(2.20 \mathrm{~g}, 7.26 \mathrm{mmol})$ to give $1.06 \mathrm{~g} \mathrm{(48 \% )}$ ) of product as a colorless oil, along with the ring-opened product $\mathbf{2 5 \mathbf { b }}$ (990 $\mathrm{mg}, 44 \%)$ as a colorless oil. Compound $\mathbf{6 c}$ : $[\mathrm{a}]{ }^{25} \mathrm{D} 36.0\left(\mathrm{c} 1.0, \mathrm{CHCl}_{3}\right) ; \mathrm{mp} 151-152{ }^{\circ} \mathrm{C}$ ( $\mathrm{HCl}$ salt); ${ }^{1} \mathrm{H}$ NMR $\delta 1.39-1.55(\mathrm{~m}, 2 \mathrm{H}), 1.50-1.75(\mathrm{~m}, 6 \mathrm{H}), 1.81-1.95(\mathrm{~m}, 2 \mathrm{H}), 2.39(\mathrm{~s}$, $3 \mathrm{H}), 2.58-2.70(\mathrm{~m}, 4 \mathrm{H}), 2.63-2.78(\mathrm{~m}, 2 \mathrm{H}), 7.15-7.38(\mathrm{~m}, 10 \mathrm{H}) \mathrm{ppm} ;{ }^{13} \mathrm{C}$ NMR $\delta 20.0$, 26.6, 32.3, 33.0, 38.0, 57.8, 125.6, 128.5, 128.6, $142.8 \mathrm{ppm}$; MS m/z $307\left(\mathrm{M}^{+}\right)$. Anal. $\left(\mathrm{C}_{22} \mathrm{H}_{29} \mathrm{~N} \cdot \mathrm{HCl} \cdot 0.2 \mathrm{H}_{2} \mathrm{O}\right) \mathrm{C}, \mathrm{H}, \mathrm{N}$. Compound 25b: $[\mathrm{a}]{ }^{25} \mathrm{D} 4.3\left(c 1.0, \mathrm{CHCl}_{3}\right) ;{ }^{1} \mathrm{H}$ NMR $\delta$ $1.24-1.50(\mathrm{~m}, 8 \mathrm{H}), 1.55-1.77(\mathrm{~m}, 4 \mathrm{H}), 2.39(\mathrm{~s}, 3 \mathrm{H}), 2.47(\mathrm{~m}, 1 \mathrm{H}), 2.56-2.68(\mathrm{~m}, 4 \mathrm{H}), 7.10$ $7.34(\mathrm{~m}, 10 \mathrm{H}) \mathrm{ppm} ;{ }^{13} \mathrm{C}$ NMR $\delta 25.8,29.5,30.1,31.7,32.3,33.5,33.6,35.4,36.2,58.9$, 125.7, 125.8, 128.3, $128.4(2 \mathrm{C}), 128.5,142.7,142.9 \mathrm{ppm} ; \mathrm{MS} \mathrm{m} / z 309\left(\mathrm{M}^{+}\right)$. Anal. $\left(\mathrm{C}_{22} \mathrm{H}_{31} \mathrm{~N} \cdot \mathrm{HCl} \cdot 0.5 \mathrm{H}_{2} \mathrm{O}\right) \mathrm{C}, \mathrm{H}, \mathrm{N}$.

\section{$N$-Methyl-2R-(E)-styryl-6S-(2-phenethyl)piperidine (13a) and $\mathrm{N}$-Methyl-2S-(E)- styryl-6S-(2-phenethyl)piperidine (13b)-Compound 11 (1.20 g, $3.76 \mathrm{mmol})$, which was prepared by dehydration of $\mathbf{1 a}$ and then epimerization in methanol, was dissolved in $10 \% \mathrm{HOAc} / \mathrm{CH}_{3} \mathrm{OH}(50 \mathrm{~mL})$, and $10 \% \mathrm{Pd} / \mathrm{C}(120 \mathrm{mg})$ was added. The mixture was hydrogenated on a Parr hydrogenation apparatus ( $45 \mathrm{psi})$ for $24 \mathrm{~h}$. The catalyst was removed by filtration through a Celite pad. The filter cake was rinsed with methanol, and the combined organic portion was concentrated under reduced pressure. The crude product 12 was dissolved in $85 \% \mathrm{H}_{3} \mathrm{PO}_{4}(30 \mathrm{~mL})$ and allowed to stir at $60{ }^{\circ} \mathrm{C}$ for $24 \mathrm{~h}$. Work up was as describe for $\mathbf{5 a}$ and $\mathbf{5 b}$ above. The dehydration product was purified by column chromatography (4:1 to 1:1 hexanes:EtOAc gradient) to give the title compound 13a (188 $\mathrm{mg}, 16 \%)$, as a white solid, and $\mathbf{1 3 b}(167 \mathrm{mg}, 15 \%)$, as a colorless oil. Compound 13a: $[\mathrm{a}]^{25} \mathrm{D} 53.8\left(\mathrm{c} 1.0, \mathrm{CHCl}_{3}\right) ; \mathrm{mp} 75-76{ }^{\circ} \mathrm{C} ;{ }^{1} \mathrm{H}$ NMR $\delta 1.30-1.89(\mathrm{~m}, 7 \mathrm{H}), 1.92-2.09(\mathrm{~m}$, $2 \mathrm{H}), 2.27(\mathrm{~s}, 3 \mathrm{H}), 2.51-2.69(\mathrm{~m}, 2 \mathrm{H}), 2.70-2.83(\mathrm{~m}, 1 \mathrm{H}), 6.21(\mathrm{dd}, J=15.9,8.4 \mathrm{~Hz}, 1 \mathrm{H})$, $6.47(\mathrm{~d}, J=15.9 \mathrm{~Hz}, 1 \mathrm{H}), 7.15-7.40(\mathrm{~m}, 10 \mathrm{H}) \mathrm{ppm} ;{ }^{13} \mathrm{C}$ NMR $\delta 24.5,31.3,31.9,33.7,36.2$, 40.3, 63.9, 68.9, 125.8, 126.3, 127.4, 128.4, 128.5, 128.7, 130.2, 134.9, 137.3, 142.9 ppm; MS m/z $305\left(\mathrm{M}^{+}\right)$. Anal. $\left(\mathrm{C}_{22} \mathrm{H}_{27} \mathrm{~N} \cdot \mathrm{HCl} \cdot{ }^{1} /{ }_{3} \mathrm{H}_{2} \mathrm{O}\right) \mathrm{C}, \mathrm{H}, \mathrm{N}$. Compound 13b: $[\mathrm{a}]^{25} \mathrm{D}-103.6(c$ $\left.1.0, \mathrm{CHCl}_{3}\right) ; \mathrm{mp} 106-107^{\circ} \mathrm{C}(\mathrm{HCl}$ salt $) ;{ }^{1} \mathrm{H}$ NMR $\delta 1.50-1.82(\mathrm{~m}, 7 \mathrm{H}), 1.84-1.98(\mathrm{~m}, 1 \mathrm{H})$, $2.32(\mathrm{~s}, 3 \mathrm{H}), 2.51(\mathrm{ddd}, J=13.5,10.8,5.7 \mathrm{~Hz}, 1 \mathrm{H}), 2.68(\mathrm{ddd}, J=13.5,10.8,5.4 \mathrm{~Hz}, 1 \mathrm{H})$, $2.83(\mathrm{~m}, 1 \mathrm{H}), 3.23(\mathrm{~m}, 1 \mathrm{H}), 6.28(\mathrm{dd}, J=15.9,8.4 \mathrm{~Hz}, 1 \mathrm{H}), 6.47(\mathrm{~d}, J=15.9 \mathrm{~Hz}, 1 \mathrm{H}), 7.13-$ $7.39(\mathrm{~m}, 10 \mathrm{H}) \mathrm{ppm} ;{ }^{13} \mathrm{C}$ NMR $\delta 19.4,28.9,29.1,32.2,33.2,40.7,58.6,61.8,125.9,126.4$, $127.4,128.4,128.5,128.7,131.0,132.0,137.3,142.7 \mathrm{ppm} ; \mathrm{MS} \mathrm{m} / z 305\left(\mathrm{M}^{+}\right)$. Anal. $\left(\mathrm{C}_{22} \mathrm{H}_{25} \mathrm{~N} \cdot \mathrm{HCl}\right) \mathrm{C}, \mathrm{H}, \mathrm{N}$.}

$N$-Methyl-2R-(2-phenylethyl)-6S-(E)-styrylpiperidine (13c) and $\mathbf{N}$-Methyl-2R-(2phenylethyl)-6R-(E)-styrylpi-peridine (13d)-Compounds $13 \mathrm{c}$ and $13 \mathrm{~d}$ were prepared by utilizing a similar procedure to that described above for compounds 13a and $\mathbf{1 3 b}$, except the starting material was compound $8(1.20 \mathrm{~g} 3.74 \mathrm{mmol})$, to give the title compound 13c (160 $\mathrm{mg}, 14 \%)$, as a white solid, and $\mathbf{1 3 d}(113 \mathrm{mg}, 10 \%)$, as a colorless oil. Compound $\mathbf{1 3 c}$ : $[\mathrm{a}]^{25} \mathrm{D}-51.5\left(\mathrm{c} 1.0, \mathrm{CHCl}_{3}\right) ; \mathrm{mp} 74-75{ }^{\circ} \mathrm{C} ;{ }^{1} \mathrm{H}$ NMR $\delta 1.30-1.84(\mathrm{~m}, 7 \mathrm{H}), 1.92-2.09(\mathrm{~m}$, $2 \mathrm{H}), 2.27(\mathrm{~s}, 3 \mathrm{H}), 2.51-2.69(\mathrm{~m}, 2 \mathrm{H}), 2.70-2.83(\mathrm{~m}, 1 \mathrm{H}), 6.21(\mathrm{dd}, J=15.9,8.4 \mathrm{~Hz}, 1 \mathrm{H})$, 
$6.47(\mathrm{~d}, J=15.9 \mathrm{~Hz}, 1 \mathrm{H}), 7.15-7.40(\mathrm{~m}, 10 \mathrm{H}) \mathrm{ppm} ;{ }^{13} \mathrm{C}$ NMR $\delta 24.5,31.2,31.9,33.7,36.2$, 40.2, 63.9, 68.9, 125.8, 126.3, 127.4, 128.4, 128.5, 128.7, 130.2, 134.8, 137.3, 142.9 ppm; MS m/z $305\left(\mathrm{M}^{+}\right)$. Anal. $\left(\mathrm{C}_{22} \mathrm{H}_{27} \mathrm{~N} \cdot \mathrm{HCl}\right) \mathrm{C}, \mathrm{H}, \mathrm{N}$. Compound 13d: [a] $]_{\mathrm{D}}^{25} 103.5(c 1.0$, $\left.\mathrm{CHCl}_{3}\right) ; \mathrm{mp} 105-106{ }^{\circ} \mathrm{C}\left(\mathrm{HCl}\right.$ salt); ${ }^{1} \mathrm{H}$ NMR $\delta 1.52-1.85(\mathrm{~m}, 7 \mathrm{H}), 1.85-1.90(\mathrm{~m}, 1 \mathrm{H}), 2.32$ (s, 3H), 2.51 (ddd, $J=13.5,10.8,5.7 \mathrm{~Hz}, 1 \mathrm{H}), 2.68$ (ddd, $J=13.5,10.8,5.7 \mathrm{~Hz}, 1 \mathrm{H}), 2.85$ $(\mathrm{m}, 1 \mathrm{H}), 3.25(\mathrm{~m}, 1 \mathrm{H}), 6.28(\mathrm{dd}, J=15.9,8.4 \mathrm{~Hz}, 1 \mathrm{H}), 6.47(\mathrm{~d}, J=15.9 \mathrm{~Hz}, 1 \mathrm{H}), 7.11-7.41$ (m, 10H) ppm; ${ }^{13} \mathrm{C}$ NMR $\delta 19.2,28.7,29.0,32.0,33.1,40.5,58.6,61.9,125.9,126.3$, $127.5,128.3,128.5,128.6,131.3,131.4,137.1,142.5 \mathrm{ppm} ; \mathrm{MS} \mathrm{m} / z 305\left(\mathrm{M}^{+}\right)$. Anal. $\left(\mathrm{C}_{22} \mathrm{H}_{25} \mathrm{~N} \cdot \mathrm{HCl}\right) \mathrm{C}, \mathrm{H}, \mathrm{N}$.

(-)-N-Methyl-2,6-cis-diphenethyl-1,2,3,6-tetrahydro-pyridine (17)-Compound 15 (colorless crystals recrystallized from benzene, $\mathrm{mp} 167-168^{\circ} \mathrm{C}$ ) was synthesized from the condensation reaction of 2,6-lutidine with benzaldehyde utilizing the reported procedure. ${ }^{32}$ The double bonds of the 2,6-side chains of compound 15 were then reduced by Pd-C catalytic hydrogenation, and the resulting product was treated with methyl $p$ toluenesulfonate following the reported procedure, ${ }^{32}$ to afford the $N$-methylated compound 16 (yellow crystals recrystallized from methanol, mp $238-239{ }^{\circ} \mathrm{C}$ ). $\mathrm{NaBH}_{4}(160 \mathrm{mg}, 4.22$ mmol) was added to a suspension of compound $16(2.00 \mathrm{~g}, 4.22 \mathrm{mmol})$ in absolute ethanol $(100 \mathrm{~mL})$ at $0{ }^{\circ} \mathrm{C}$. The mixture was stirred for $2 \mathrm{~h}$ and then quenched with acetone. Solvent was removed under reduced pressure and the residue was taken up in water $(50 \mathrm{~mL})$ and extracted with $\mathrm{CHCl}_{3}(50 \mathrm{~mL} \times 3)$. The combined organic extracts were dried over $\mathrm{Na}_{2} \mathrm{SO}_{4}$, filtered, and concentrated. The crude product was purified by silica gel column chromatography (1:1 hexanes: EtOAc) to give the title compound $\mathbf{1 7}(245 \mathrm{mg}, 19 \%)$ as a white solid: mp $162-163{ }^{\circ} \mathrm{C}$ ( $\mathrm{HCl}$ salt); ${ }^{1} \mathrm{H}$ NMR $\delta 1.62-1.97(\mathrm{~m}, 4 \mathrm{H}), 1.99(\mathrm{~m}, 2 \mathrm{H}), 2.19$ (s, 3H), 2.60-2.81 (m, 5H), 3.09 (m, 1H), 5.52 (ddd, $J=10.2,3.6,1.8 \mathrm{~Hz}, 1 \mathrm{H}), 5.78$ (ddd, $J$ $=10.2,3.9,3.0 \mathrm{~Hz}, 1 \mathrm{H}), 7.13-7.32(\mathrm{~m}, 10 \mathrm{H}) \mathrm{ppm} ;{ }^{13} \mathrm{C}$ NMR $\delta 28.4,32.2,32.3,32.9,35.6$, $36.0,58.5,61.2,125.6,125.8,128.4,128.5,128.6,128.8,142.76,142.82 \mathrm{ppm} ; \mathrm{MS} \mathrm{m} / z 305$ $\left(\mathrm{M}^{+}\right)$. Anal. $\left(\mathrm{C}_{22} \mathrm{H}_{27} \mathrm{~N} \cdot \mathrm{HCl} \cdot 0.5 \mathrm{H}_{2} \mathrm{O}\right) \mathrm{C}, \mathrm{H}, \mathrm{N}$.

( \pm )-N-Methyl-2,6-cis-2-phenethyl-6-(E)-styryl-1,2,5,6-tetrahydropyridine (19)— Compound $\mathbf{1 9}$ was prepared by utilizing a procedure similar to that described above for $\mathbf{1 7}$, except the starting material was compound $\mathbf{1 8}^{32}(1.08 \mathrm{~g}, 2.30 \mathrm{mmol})$, to give title compound $19(265 \mathrm{mg}, 38 \%)$ as a white solid. $\mathrm{mp} 90-91{ }^{\circ} \mathrm{C} ;{ }^{1} \mathrm{H}$ NMR $\delta 1.85-1.96(\mathrm{~m}, 2 \mathrm{H}), 2.04(\mathrm{~m}$, $1 \mathrm{H}), 2.22(\mathrm{~m}, 1 \mathrm{H}), 2.29(\mathrm{~s}, 3 \mathrm{H}), 2.59(\mathrm{~m}, 1 \mathrm{H}), 2.79(\mathrm{~m}, 1 \mathrm{H}), 2.85(\mathrm{~m}, 1 \mathrm{H}), 3.00(\mathrm{~m}, 1 \mathrm{H})$, $5.64(\mathrm{~d}, J=10.2 \mathrm{~Hz}, 1 \mathrm{H}), 5.82(\mathrm{~m}, 1 \mathrm{H}), 6.21(\mathrm{dd}, J=15.9,8.4 \mathrm{~Hz}, 1 \mathrm{H}), 6.51(\mathrm{~d}, J=15.9 \mathrm{~Hz}$, 1H), 7.13-7.41 (m, 10H) ppm; ${ }^{13} \mathrm{C}$ NMR $\delta 31.2,33.1,35.6,40.3,62.6,64.2,124.6,125.7$, $126.4,127.5,128.4,128.7,129.2,130.6,133.7,137.1,142.8$ ppm; MS m/z $303\left(\mathrm{M}^{+}\right)$. Anal. $\left(\mathrm{C}_{22} \mathrm{H}_{25} \mathrm{~N} \cdot \mathrm{HCl}\right) \mathrm{C}, \mathrm{H}, \mathrm{N}$.

2,6-cis-Diphenethylpiperidine (20)-mp 199-200 ${ }^{\circ} \mathrm{C}$ ( $\mathrm{HCl}$ salt) (lit. ${ }^{32} \mathrm{mp}$ 192-194 $\left.{ }^{\circ} \mathrm{C}\right) ;{ }^{1} \mathrm{H}$ NMR $\delta 1.07(\mathrm{ddd}, J=24.0,13.2,3.9 \mathrm{~Hz}, 2 \mathrm{H}), 1.32(\mathrm{ddt}, J=26.4,12.9,3.9 \mathrm{~Hz}, 1 \mathrm{H})$, $1.62-1.74(\mathrm{~m}, 6 \mathrm{H}), 1.78(\mathrm{dq}, J=13.2,3.0 \mathrm{~Hz}, 1 \mathrm{H}), 2.50(\mathrm{~m}, 2 \mathrm{H}), 2.63(\mathrm{t}, J=8.1 \mathrm{~Hz}, 4 \mathrm{H})$, 7.12-7.33 (m, 10H) ppm; ${ }^{13} \mathrm{C}$ NMR $\delta 25.0,32.7,32.9,39.2,56.9,125.9,128.4,128.5$, $142.3 \mathrm{ppm} ; \mathrm{MS} \mathrm{m} / z 293\left(\mathrm{M}^{+}\right)$. Anal. $\left(\mathrm{C}_{21} \mathrm{H}_{27} \mathrm{~N} \cdot \mathrm{HCl}\right) \mathrm{C}, \mathrm{H}, \mathrm{N}$.

\section{2,6-cis-Di-(E)-styrylpiperidine (22a) and ( \pm )-2,6-trans-Di-(E)-styrylpiperidine} $(\mathbf{2 2 b} / \mathbf{c})$-Norlobelanine (21) was prepared according to a reported method. ${ }^{31}$ Utilizing a similar procedure to that described for the preparation of $\mathbf{5 a}$ and $\mathbf{5 b}$ from lobeline $(\mathbf{1} \mathbf{a} / \mathbf{1} \mathbf{b})$, compounds 22a (18\%) and 22b (13\%) were obtained in pure form from norlobelanine (21). Compound 22a: mp 226-227 ${ }^{\circ} \mathrm{C}$ ( $\mathrm{HCl}$ salt); ${ }^{1} \mathrm{H}$ NMR $\delta 1.23-1.62(\mathrm{~m}, 3 \mathrm{H}), 1.75$ (dd, $J=$ $12.3,3.0 \mathrm{~Hz}, 2 \mathrm{H}), 1.91(\mathrm{~m}, 1 \mathrm{H}), 3.37(\mathrm{t}, J=8.1 \mathrm{~Hz}, 2 \mathrm{H}), 6.26(\mathrm{dd}, J=15.9,7.2 \mathrm{~Hz}, 2 \mathrm{H})$, $6.54(\mathrm{~d}, J=15.9 \mathrm{~Hz}, 2 \mathrm{H}), 7.17-7.40(\mathrm{~m}, 10 \mathrm{H}) \mathrm{ppm} ;{ }^{13} \mathrm{C}$ NMR $\delta 24.7,32.4,59.7,126.4$, 
127.4, 128.6, 129.6, 133.4, $137.2 \mathrm{ppm}$; MS m/z $289\left(\mathrm{M}^{+}\right)$. Anal. $\left(\mathrm{C}_{21} \mathrm{H}_{23} \mathrm{~N} \cdot \mathrm{HCl}\right) \mathrm{C}, \mathrm{H}, \mathrm{N}$. Compound 22b/c: mp 194-195 ${ }^{\circ} \mathrm{C}$ ( $\mathrm{HCl}$ salt); ${ }^{1} \mathrm{H}$ NMR $\delta 1.53-1.64(\mathrm{~m}, 2 \mathrm{H}), 1.64-1.78(\mathrm{~m}$, $2 \mathrm{H}), 1.78-1.92(\mathrm{~m}, 2 \mathrm{H}), 3.78(\mathrm{~m}, 2 \mathrm{H}), 6.41(\mathrm{dd}, J=15.9,6.3 \mathrm{~Hz}, 2 \mathrm{H}), 6.52(\mathrm{~d}, J=15.9 \mathrm{~Hz}$, 2H), 7.19-7.43 (m, 10H) ppm; ${ }^{13} \mathrm{C}$ NMR $\delta 20.3,31.5,53.8,126.4,127.5,128.7,129.9$, $132.8,137.3 \mathrm{ppm}$; MS m/z $289\left(\mathrm{M}^{+}\right)$. Anal. $\left(\mathrm{C}_{21} \mathrm{H}_{23} \mathrm{~N} \cdot \mathrm{HCl} \cdot 0.25 \mathrm{H}_{2} \mathrm{O}\right) \mathrm{C}, \mathrm{H}, \mathrm{N}$.

$\mathrm{N}, \mathrm{N}$-Dimethyl-2,6-cis-di-(E)-styrylpiperidine lodide (23a)—Iodomethane (490 mg, $3.45 \mathrm{mmol})$ was added to a stirred solution of compound $\mathbf{5 a}(350 \mathrm{mg}, 1.15 \mathrm{mmol})$ in acetone $(8 \mathrm{~mL})$, and the stirring was continued for $24 \mathrm{~h}$. The solvent was removed under reduced pressure, and the residue was washed thoroughly with $\mathrm{Et}_{2} \mathrm{O}$ to afford the title compound 23a as a white solid (460 mg, 90\%): $\mathrm{mp} 223-224{ }^{\circ} \mathrm{C} ;{ }^{1} \mathrm{H}$ NMR $\delta 1.89-2.07(\mathrm{~m}, 3 \mathrm{H}), 2.09-2.25$ (m, 3H), 2.93 (s, 3H), 3.34 (s, 3H), 5.36 (brt, $J=9.0 \mathrm{~Hz}, 2 \mathrm{H}), 6.17$ (dd, $J=15.9,9.6 \mathrm{~Hz}$, 2H), $7.25(\mathrm{~d}, J=15.9 \mathrm{~Hz}, 2 \mathrm{H}), 7.30-7.39(\mathrm{~m}, 6 \mathrm{H}), 7.44-7.52(\mathrm{~m}, 4 \mathrm{H}) \mathrm{ppm} ;{ }^{13} \mathrm{C}$ NMR $\delta$ 21.7, 27.7, 38.6, 50.5, 73.9, 118.9, 127.4, 128.9, 129.6, 134.6, $142.0 \mathrm{ppm} ; \mathrm{MS} \mathrm{m} / z$ maldi $318(\mathrm{M}-127)^{+}$. Anal. $\left(\mathrm{C}_{23} \mathrm{H}_{28} \mathrm{NI}\right) \mathrm{C}, \mathrm{H}, \mathrm{N}$.

$N, N$-Dimethyl-2S,6S-trans-di-(E)-styrylpiperidine lodide (23b)—Compound 23b was prepared by utilizing a similar procedure to that described above for 23a, except using the starting material $\mathbf{5 b}(50 \mathrm{mg}, 0.16 \mathrm{mmol})$, to give $69 \mathrm{mg}(95 \%)$ of product as a white solid: $[\mathrm{a}]^{25} \mathrm{D}-182.8\left(\mathrm{c} 0.5, \mathrm{CHCl}_{3}\right) ; \mathrm{mp} 126-127{ }^{\circ} \mathrm{C} ;{ }^{1} \mathrm{H}$ NMR $\delta 1.65-2.30(\mathrm{~m}, 6 \mathrm{H}), 3.28$ $(\mathrm{s}, 6 \mathrm{H}), 4.71(\mathrm{~m}, 2 \mathrm{H}), 6.44(\mathrm{dd}, J=15.6,9.9 \mathrm{~Hz}, 2 \mathrm{H}), 7.21(\mathrm{~d}, J=15.6 \mathrm{~Hz}, 2 \mathrm{H}), 7.26-7.40$ $(\mathrm{m}, 6 \mathrm{H}), 7.51-59(\mathrm{~m}, 4 \mathrm{H}) \mathrm{ppm} ;{ }^{13} \mathrm{C}$ NMR $\delta 17.5,26.8,48.7,71.8,118.3,127.6,129.0$, 129.6, 134.7, 141.7 ppm; MS (maldi) $\mathrm{m} / z 318(\mathrm{M}-127)^{+}$. Anal. $\left(\mathrm{C}_{23} \mathrm{H}_{28} \mathrm{NI}\right) \mathrm{C}, \mathrm{H}, \mathrm{N}$.

$\mathbf{N}, \mathrm{N}$-Dimethyl-2,6-cis-bis(2-phenethyl)piperidine lodide (24a)—Compound 24a was prepared by utilizing a similar procedure to that described above for 23a, except using the starting material 6a $(116 \mathrm{mg}, 0.38 \mathrm{mmol})$ to give $166 \mathrm{mg}(97 \%)$, to produce a white solid: $\mathrm{mp} 241-242{ }^{\circ} \mathrm{C} ;{ }^{1} \mathrm{H}$ NMR $\delta 1.69-1.95(\mathrm{~m}, 6 \mathrm{H}), 2.04-2.18(\mathrm{~m}, 2 \mathrm{H}), 2.28-2.43(\mathrm{~m}$, $2 \mathrm{H}), 2.67-2.86(\mathrm{~m}, 4 \mathrm{H}), 2.85(\mathrm{~s}, 3 \mathrm{H}), 3.21(\mathrm{~s}, 3 \mathrm{H}), 3.73(\mathrm{~m}, 2 \mathrm{H}), 7.19-7.35(\mathrm{~m}, 10 \mathrm{H})$ ppm; ${ }^{13} \mathrm{C}$ NMR $\delta 22.0,26.8,32.3,33.0,38.4,50.1,74.5,126.9,128.6,128.9,139.5$ ppm; MS (maldi) $\mathrm{m} / z 322(\mathrm{M}-127)^{+}$. Anal. $\left(\mathrm{C}_{23} \mathrm{H}_{32} \mathrm{NI} \cdot{ }^{1} /{ }_{3} \mathrm{H}_{2} \mathrm{O}\right) \mathrm{C}, \mathrm{H}, \mathrm{N}$.

$N, N$-Dimethyl-2S,6S-trans-bis(2-phenethyl)piperidine lodide (24b)—Compound 24b was prepared by utilizing a similar procedure to that described above for 23a, except using the starting material $\mathbf{6 b}(58 \mathrm{mg}, 0.19 \mathrm{mmol})$, to give $82 \mathrm{mg}(96 \%)$ of product as a white solid: $[\mathrm{a}]^{25} \mathrm{D}-37.1\left(\mathrm{c} 0.3, \mathrm{CHCl}_{3}\right) ; \mathrm{mp} 222-223{ }^{\circ} \mathrm{C} ;{ }^{1} \mathrm{H}$ NMR $\delta 1.70-2.00(\mathrm{~m}, 6 \mathrm{H})$, 2.08-2.32 (m, 4H), 2.67-2.82 (m, 4H), 3.25 (s, 6H), $3.73(\mathrm{~m}, 2 \mathrm{H}), 7.18-7.36(\mathrm{~m}, 10 \mathrm{H})$ ppm; ${ }^{13} \mathrm{C}$ NMR $\delta 16.8,24.1,29.4,32.6,49.3,70.0,126.9,128.6,128.9,139.5$ ppm; MS (maldi) $\mathrm{m} / z 322(\mathrm{M}-127)^{+}$. Anal. $\left(\mathrm{C}_{23} \mathrm{H}_{32} \mathrm{NI} \cdot 0.5 \mathrm{H}_{2} \mathrm{O}\right) \mathrm{C}, \mathrm{H}, \mathrm{N}$.

2,6-cis-Bis(1-naphthalenethyl)piperidine (28a)-Utilizing a similar procedure ${ }^{32}$ to that described for compound 20, compound 28a was prepared from 2,6-lutidine and 1-naphthaldehyde: $\mathrm{mp} 218-219{ }^{\circ} \mathrm{C}\left(\mathrm{HCl}\right.$ salt); ${ }^{1} \mathrm{H}$ NMR $\delta 1.16$ (ddd, $\left.J=23.4,13.2,3.3 \mathrm{~Hz}, 2 \mathrm{H}\right)$, 1.39 (ddt, $J=26.4,13.2,3.3 \mathrm{~Hz}, 1 \mathrm{H}), 1.72-1.92(\mathrm{~m}, 7 \mathrm{H}), 2.63(\mathrm{~m}, 2 \mathrm{H}), 3.09(\mathrm{dd}, J=9.0,6.3$ $\mathrm{Hz}, 4 \mathrm{H}), 7.29-7.42(\mathrm{~m}, 4 \mathrm{H}), 7.42-7.53(\mathrm{~m}, 4 \mathrm{H}), 7.70$ (d, $J=7.8 \mathrm{~Hz}, 2 \mathrm{H}), 7.84$ (dd, $J=7.2$, $2.4 \mathrm{~Hz}, 2 \mathrm{H}), 8.04(\mathrm{~d}, J=7.5 \mathrm{~Hz}, 2 \mathrm{H}) \mathrm{ppm} ;{ }^{13} \mathrm{C}$ NMR $\delta 25.1,29.9,32.9,38.6,57.4,124.0$, $125.6,125.7,125.9,126.0,126.7,128.9,131.9,134.0,138.5$ ppm; MS (maldi) $\mathrm{m} / z 394$ (M $+1)^{+}$. Anal. $\left(\mathrm{C}_{29} \mathrm{H}_{31} \mathrm{~N} \cdot \mathrm{HCl}\right) \mathrm{C}, \mathrm{H}, \mathrm{N}$.

N-Methyl-2,6-cis-bis(1-naphthalenethyl)piperidine(28b)- $\mathrm{NaBH}_{3} \mathrm{CN}$ (344 mg, 5.50 $\mathrm{mmol}$ ) was added to a mixture of $\mathbf{2 8 a}$ (434 $\mathrm{mg}, 1.10 \mathrm{mmol}$ ), paraformaldehyde (330 $\mathrm{mg}$, $11.00 \mathrm{mmol})$, and methanol $(10 \mathrm{~mL})$. The mixture was stirred at room temperature 
overnight. The solvent was then evaporated under reduced pressure. The residue was dissolved in water $(30 \mathrm{~mL})$ and the aqueous solution was extracted with $\mathrm{CHCl}_{3}(20 \mathrm{~mL} \times 3)$. The combined organic extracts were dried over $\mathrm{Na}_{2} \mathrm{SO}_{4}$, filtered, and concentrated. The crude product was purified by silica gel column chromatography $\left(30: 1 \mathrm{CHCl}_{3}: \mathrm{MeOH}\right)$ to afford $425 \mathrm{mg}$ (95\%) of $\mathbf{2 8 b}$ as a white solid. $\mathrm{mp} 217-218^{\circ} \mathrm{C}$ ( $\mathrm{HCl}$ salt); ${ }^{1} \mathrm{H}$ NMR $\delta 1.40$ $1.64(\mathrm{~m}, 4 \mathrm{H}), 1.68-1.90(\mathrm{~m}, 4 \mathrm{H}), 2.03(\mathrm{~m}, 2 \mathrm{H}), 2.24$ (s, 3H), 2.61 (m, 2H), 3.09 (dd, $J=9.0$, $6.3 \mathrm{~Hz}, 4 \mathrm{H}), 3.18(\mathrm{t}, J=8.1 \mathrm{~Hz}, 4 \mathrm{H}), 7.34-7.41(\mathrm{~m}, 4 \mathrm{H}), 7.42-7.54(\mathrm{~m}, 4 \mathrm{H}), 7.71(\mathrm{dd}, J=$ $6.3,2.7 \mathrm{~Hz}, 2 \mathrm{H}), 7.85(\mathrm{dd}, J=7.5,1.5 \mathrm{~Hz}, 2 \mathrm{H}), 8.11(\mathrm{~d}, J=8.1 \mathrm{~Hz}, 2 \mathrm{H}) \mathrm{ppm} ;{ }^{13} \mathrm{C}$ NMR $\delta$ 25.3, 26.7, 29.6, 30.5, 35.8, 63.1, 124.0, 125.5, 125.7, 125.9, 126.1, 126.6, 128.9, 132.0, 134.0, $139.1 \mathrm{ppm}$; MS (maldi) $\mathrm{m} / z 408(\mathrm{M}+1)^{+}$. Anal. $\left(\mathrm{C}_{30} \mathrm{H}_{33} \mathrm{~N} \cdot \mathrm{HCl} \cdot 0.75 \mathrm{H}_{2} \mathrm{O}\right) \mathrm{C}, \mathrm{H}, \mathrm{N}$.

2,6-cis-Bis(2-naphthalenethyl)piperidine (29a)—By utilizing a similar procedure to that described for the preparation of compound $\mathbf{2 0},{ }^{32}$ compound 29a was prepared from 2,6lutidine and 2-naphthaldehyde: $\mathrm{mp} 222-223{ }^{\circ} \mathrm{C}$ ( $\mathrm{HCl}$ salt); ${ }^{1} \mathrm{H}$ NMR $\delta 1.12$ (ddd, $J=23.7$, $12.9,3.0 \mathrm{~Hz}, 2 \mathrm{H}), 1.39$ (ddt, $J=25.8,12.9,3.6 \mathrm{~Hz}, 1 \mathrm{H}), 1.60-1.86(\mathrm{~m}, 7 \mathrm{H}), 2.52(\mathrm{~m}, 2 \mathrm{H})$, $2.77(\mathrm{t}, J=7.8 \mathrm{~Hz}, 4 \mathrm{H}), 7.30$ (dd, $J=8.7,1.2 \mathrm{~Hz}, 2 \mathrm{H}), 7.36-7.47(\mathrm{~m}, 4 \mathrm{H}), 7.58$ (brs, $2 \mathrm{H}$ ), 7.71-7.82 (m, 6H) ppm; ${ }^{13} \mathrm{C}$ NMR $\delta 25.0,32.8,32.9,39.0,56.9,125.2,126.0,126.4,127.4$, $127.5,127.7,128.0,132.1,133.7,139.8 \mathrm{ppm}$; MS (maldi) $\mathrm{m} / \mathrm{z} 394(\mathrm{M}+1)^{+}$. Anal. $\left(\mathrm{C}_{29} \mathrm{H}_{31} \mathrm{~N} \cdot \mathrm{HCl} \cdot 0.5 \mathrm{H}_{2} \mathrm{O}\right) \mathrm{C}, \mathrm{H}, \mathrm{N}$.

N-Methyl-2,6-cis-bis(2-naphthalenethyl)piperidine(29b)—Utilizing a similar procedure to that described for the preparation of compound $\mathbf{2 8 b}$, compound $\mathbf{2 9 b}$ was prepared from 29a: mp 230-231 ${ }^{\circ} \mathrm{C}\left(\mathrm{HCl}\right.$ salt); ${ }^{1} \mathrm{H}$ NMR $\delta 1.33-1.45(\mathrm{~m}, 4 \mathrm{H}), 1.70-1.83$ $(\mathrm{m}, 4 \mathrm{H}), 2.02(\mathrm{~m}, 2 \mathrm{H}), 2.23(\mathrm{~s}, 3 \mathrm{H}), 2.48(\mathrm{~m}, 2 \mathrm{H}), 2.85(\mathrm{~m}, 4 \mathrm{H}), 7.35(\mathrm{dd}, J=6.6,1.5 \mathrm{~Hz}$, 2H), 7.38-7.46 (m, 4H), 7.65 (brs, 2H), 7.74-7.82 (m, 6H) ppm; ${ }^{13} \mathrm{C}$ NMR $\delta 25.2,29.7$, 30.1, 32.9, 36.5, 64.1, 125.9, 126.1, 126.5, 127.6, 127.7, 127.8, 128.2, 131.9, 133.6, 139.7 ppm. MS (maldi) $\mathrm{m} / z 408(\mathrm{M}+1)^{+}$. Anal. $\left(\mathrm{C}_{30} \mathrm{H}_{33} \mathrm{~N} \cdot \mathrm{HCl} \cdot 0.75 \mathrm{H}_{2} \mathrm{O}\right) \mathrm{C}, \mathrm{H}, \mathrm{N}$.

\section{$\left[{ }^{3} \mathrm{H}\right] \mathrm{NIC}$ and $\left[{ }^{3} \mathrm{H}\right] \mathrm{MLA}$ Binding Assay}

Rat striatal and whole brain (excluding cerebellum) membranes were used for the $\left[{ }^{3} \mathrm{H}\right] \mathrm{NIC}$ and $\left[{ }^{3} \mathrm{H}\right] \mathrm{MLA}$ binding assays, respectively. Membrane suspensions (150-200 $\left.\mu \mathrm{g} / 100 \mu \mathrm{L}\right)$ were added to assay tubes containing analogue (7-9 concentrations, $1 \mathrm{nM}-1 \mathrm{mM}$ ) and $3 \mathrm{nM}$ $\left[{ }^{3} \mathrm{H}\right] \mathrm{NIC}$ or $\left[{ }^{3} \mathrm{H}\right]$ MLA for a final assay volume of $200-250 \mu \mathrm{L}$. For the $\left[{ }^{3} \mathrm{H}\right] \mathrm{NIC}$ and $\left[{ }^{3} \mathrm{H}\right]$ MLA binding assays, tubes were incubated for 90 and $120 \mathrm{~min}$, respectively. Reactions were terminated by addition of ice-cold buffer and rapid filtration onto either Whatman GF/ B glass fiber filters presoaked in $0.5 \%$ polyethylenimine using a Brandel Harvester (Biomedical Research and Development Laboratory, Inc., Gaithersburg, MD) or onto Unifilter-96 GF/B 96-well filter plates also presoaked in $0.5 \%$ polyethylenimine using a Packard Filter Mate Harvester (Packard BioScience Co., Meriden, CT). Bound radioactivity was determined via liquid scintillation spectrometry. Nonspecific binding was determined in the presence of $10 \mu \mathrm{M}$ NIC for the $\left[{ }^{3} \mathrm{H}\right] \mathrm{NIC}$ binding assay and in the presence of $10 \mu \mathrm{M}$ MLA or $1 \mathrm{mM}$ NIC for the $\left[{ }^{3} \mathrm{H}\right]$ MLA binding assays.

\section{Preparation of Rat Brain Synaptic Vesicles}

Synaptic vesicles were prepared as previously described. ${ }^{15}$ Briefly, fresh whole brain (excluding cerebellum and brain stem) was homogenized in $20 \mathrm{vol}$ of ice-cold $0.32 \mathrm{M}$ sucrose using a glass homogenizer (seven strokes of a Teflon pestle, clearance $=0.003 \mathrm{in}$ ). Homogenates were centrifuged at $1000 \mathrm{~g}$ for $12 \mathrm{~min}$ at $4{ }^{\circ} \mathrm{C}$. Resulting supernatants (S1) were centrifuged at $22000 \mathrm{~g}$ for $10 \mathrm{~min}$. The resulting pellets (P2), containing the synaptosomes, were resuspended in $18 \mathrm{~mL}$ of ice-cold Milli-Q water for $5 \mathrm{~min}$ with seven strokes of the Teflon pestle homogenizer. Osmolarity was restored by immediate addition of $2 \mathrm{~mL}$ of $25 \mathrm{mM}$ HEPES and $100 \mathrm{mM} K_{2}$-tartrate buffer (pH 7.5). Samples were centrifuged 
at $20000 \mathrm{~g}$ for $20 \mathrm{~min} . \mathrm{MgSO}_{4}$ (final concentration, $1 \mathrm{mM}$ ) was added to the resulting supernatants (S3). Final centrifugations were performed at 100 000g for $45 \mathrm{~min}$. Pellets (P4) were resuspended immediately in ice-cold buffer (see below) providing $\sim 15 \mu \mathrm{g}$ of protein/ $100 \mu \mathrm{L}$.

\section{$\left[{ }^{3} \mathrm{H}\right] \mathrm{DHTBZ}$ Binding Assay}

$\left[{ }^{3} \mathrm{H}\right]$ DHTBZ binding to synaptic vesicles was performed according to previously described procedures. ${ }^{16}$ Briefly, $100 \mu \mathrm{L}$ of vesicles suspension was incubated in assay buffer (in 25 mM HEPES, $100 \mathrm{mM} \mathrm{K}_{2}$ tartrate, $5 \mathrm{mM} \mathrm{MgSO}_{4}, 0.1 \mathrm{mM}$ EDTA, and $0.05 \mathrm{mM}$ EGTA, pH $7.5,25^{\circ} \mathrm{C}$ ) in the presence of $5 \mathrm{nM}\left[{ }^{3} \mathrm{H}\right] \mathrm{DHTBZ}$ and $1 \mathrm{nM}-1 \mathrm{mM}$ lobeline analogues (final concentrations) for $30 \mathrm{~min}$ at room temperature. Nonspecific binding was determined in the presence of $20 \mu \mathrm{M}$ TBZ. Assays were performed in duplicate using the Unifilter-96 96-well GF/B filter plates (presoaked in $0.5 \%$ polyethylenimine) plates and terminated by harvesting using the FilterMate harvester. After washing five times with $350 \mu \mathrm{L}$ of the ice-cold wash buffer (in $25 \mathrm{mM}$ HEPES, $100 \mathrm{mM} \mathrm{K}_{2}$ tartrate, $5 \mathrm{mM} \mathrm{MgSO}_{4}$, and $10 \mathrm{mM} \mathrm{NaCl}$, $\mathrm{pH} 7.5$ ), filter plates were dried, bottoms were sealed, and each well was filled with $40 \mu \mathrm{L}$ of Packard's MicroScint 20 cocktail. Bound $\left[{ }^{3} \mathrm{H}\right]$ DHTBZ was measured using a Packard TopCount NXT scintillation counter and a Packard Windows NT-based operating system.

\section{Supplementary Material}

Refer to Web version on PubMed Central for supplementary material.

\section{Acknowledgments}

This research was supported by NIH grants DA 00399 and DA 13519. The authors also gratefully acknowledge the generous gift of $\left[{ }^{3} \mathrm{H}\right] \mathrm{DTBZ}$ from Dr. Michael R. Kilbourn (supported by NIH grant MH 47611). The authors also thank Mr. Robert King of Environmental Research and Training Laboratory, University of Kentucky, for the elemental analyses. For purposes of full disclosure, the University of Kentucky holds patents on lobeline and lobeline analogues that have been licensed by Yaupon Therapeutics Inc. (Lexington, KY). A potential royalty stream to L.P.D. and P.A.C. may occur consistent with University of Kentucky policy. Both L.P.D. and P.A.C. are founders of and have financial interest in Yaupon Therapeutics Inc.

\section{References}

1. Wise RA, Bozarth MA. A psychomotor stimulant theory of addiction. Psychol Rev. 1987; 94:469492. [PubMed: 3317472]

2. Koob GF. Neural mechanisms of drug reinforcement. Ann NY Acad Sci. 1992; 654:171-191. [PubMed: 1632582]

3. Fleckenstein AE, Hanson GR. Impact of psychostimulants on vesicular monoamine transporter function. Eur J Pharmacol. 2003; 479:283-289. [PubMed: 14612158]

4. Brown JM, Hanson GR, Fleckenstein AE. Methamphetamine rapidly decrease vesicular dopamine uptake. J Neurochem. 2000; 74:2221-2223. [PubMed: 10800970]

5. Brown JM, Hanson GR, Fleckenstein AE. Regulation of the vesicular monoamine transporter-2: A novel mechanism for cocaine and other psychostimulants. J Pharmacol Exp Ther. 2001; 296:762767. [PubMed: 11181904]

6. Sulzer D, Chen TK, Lau YY, Kristensen H, Rayport S, Ewing A. Amphetamine redistributes dopamine from synaptic vesicles to the cytosol and promotes reverse transport. J Neurosci. 1995; 15:4102-4108. [PubMed: 7751968]

7. Johnson RA, Eshleman AJ, Meyers T, Neve KA, Janowsky A. $\left[{ }^{3} \mathrm{H}\right]$ Substrate- and cell-specific effects of uptake inhibitors on human dopamine and serotonin transporter-mediated efflux. Synapse. 1998; 30:97-106. [PubMed: 9704886]

8. Takahashi N, Miner LL, Sora I, Ujike H, Revay RS, Kostic V, Jackson-Lewis V, Prezedborski S, Uhl GR. VMAT2 knockout mice: Heterozygotes display reduced amphetamine conditioned reward 
enhanced amphetamine locomotion enhanced MPTP toxicity. Proc Natl Acad Sci USA. 1997; 94:9938-9943. [PubMed: 9275230]

9. Wang Y, Gainetdinov RR, Fumagalli F, Xu F, Jones SR, Bock CB, Miller GW, Wightman RM, Caron MG. Knockout of the vesicular monoamine transporter 2 gene results in neonatal death and supersensitivity to cocaine and amphetamine. Neuron. 1997; 19:1285-1296. [PubMed: 9427251]

10. Fuente-Fernandez RDL, Furtado S, Guttman M, Furukawa Y, Lee CS, Calne DB, Ruth TJ, Stoessl AJ. VMAT2 binding is elevated in dopa-responsive dystonia: Visualizing empty vesicles by PET. Synapse. 2003; 49:20-28. and references therein. [PubMed: 12710012]

11. Rocha BA, Fumagalli F, Gainetdinov RR, Jones SR, Ator R, Giros B, Miller GW, Caron MG. Cocaine self-administration in dopamine transporter knockout mice. Nat Neurosci. 1998; 1:132137. [PubMed: 10195128]

12. Sora I, Wichems C, Takahashi N, Li XF, Zeng Z, Revay R, Lesch KP, Murphy DL, Uhl GR. Cocaine reward models: Conditioned place preference can be established in dopamine- and in serotonin-transporter knock out mice. Proc Natl Acad Sci US A. 1998; 95:7699-7704.

13. Pletscher A, Brossi A, Gey KF. Benzoquinolizine derivatives: A new class of monoamine decreasing drugs with psychotropic action. Int Rev Neurobil. 1962; 4:275-306.

14. Dwoskin LP, Crooks PA. A novel mechanism and potential use for lobeline as a treatment for psychostimulant abuse. Biochem Pharmacol. 2002; 63:89-98. [PubMed: 11841781]

15. Teng L, Crooks PA, Sonsalla PK, Dwoskin LP. Lobeline and nicotine evoke $\left[{ }^{3} \mathrm{H}\right]$ overflow from rat striatal slices preloaded with $\left[{ }^{3} \mathrm{H}\right]$ dopamine: Differential inhibition of synaptosomal and vesicular $\left[{ }^{3} \mathrm{H}\right]$ dopamine uptake. J Pharmacol Exp Ther. 1997; 280:1432-1444. [PubMed: 9067333]

16. Teng L, Crooks PA, Dwoskin LP. Lobeline displaces $\left[{ }^{3} \mathrm{H}\right]$ dihydroxytetrabenazine binding and releases $\left[{ }^{3} \mathrm{H}\right]$ dopamine from rat striatal synaptic vesicles: Comparison with $d$-amphetamine. $\mathrm{J}$ Neurochem. 1998; 71:258-265. [PubMed: 9648873]

17. Miller DK, Crooks PA, Teng L, Witkin JM, Munzar P, Goldberg SR, Acri JB, Dwoskin LP. Lobeline inhibits the neurochemical and behavioral effects of amphetamine. J Pharmacol Exp Ther. 2001; 296:1023-1034. [PubMed: 11181937]

18. Harrod SB, Dwoskin LP, Crooks PA, Klebaur JE, Bardo MT. Lobeline attenuates $d$ methamphetamine self-administration in rats. J Pharmacol Exp Ther. 2001; 298:172-179. [PubMed: 11408539]

19. Harrod SB, Dwoskin LP, Green TA, Gehrke BJ, Bardo MT. Lobeline does not serve as a reinforcer in rats. Psychopharmacology. 2003; 165:397-404. [PubMed: 12459929]

20. Miller DK, Harrod SB, Green TA, Wong MY, Bardo MT, Dwoskin LP. Lobeline attenuates the locomotor stimulation induced by repeated nicotine administration in rats. Pharmacol Biochem Behav. 2002; 74:279-286. [PubMed: 12479946]

21. Miller DK, Crooks PA, Dwoskin LP. Lobeline inhibits nicotine-evoked [ $\left.{ }^{3} \mathrm{H}\right]$ dopamine overflow from rat striatal slices and nicotine-evoked ${ }^{86} \mathrm{Rb}^{+}$efflux from thalamic synaptosomes. Neuropharmacology. 2000; 39:2654-2662. [PubMed: 11044735]

22. Miller DK, Crooks PA, Zheng G, Grinevich VP, Norrholm S, Dwoskin LP. Lobeline analogues with enhanced affinity and selectivity for plasmalemma and vesicular mono-amine transporters and diminished affinity at $a 4 \beta 2^{*}$ and $a 7^{*}$ nAChRs. J Pharmacol Exp Ther. 2004; 310:1035-1045. [PubMed: 15121762]

23. Briggs CA, McKenna DG. Activation and inhibition of the human a 7 nicotinic acetylcholine receptor by agonist binding affinity. Neuropharmacology. 1998; 37:1095-1102. [PubMed: 9833639]

24. Crooks PA, Jones MD, Chesnut MD, Jaromczyk AM, Dwoskin LP. Stereochemically defined lobeline analogues: Inhibition of $\left[{ }^{3} \mathrm{H}\right]$ dopamine uptake and $\left[{ }^{3} \mathrm{H}\right]$ nicotine binding in rat striatum. College Problems Drug Dependence. 1999; 61:29.

25. Flammia D, Malgorzata D, Damaj MI, Martin B, Glennon RA. Lobeline: Structure-affinity investigation of nicotinic acetylcholinergic receptor binding. J Med Chem. 1999; 42:3726-3731. [PubMed: 10479304]

26. Perera RP, Wimalasena DS, Wimalasena K. Characterization of a series of 3-amino-2phenylpropene derivatives as novel bovine chromaffin vesicular monoamine transporter inhibitors. J Med Chem. 2003; 46:2599-2605. [PubMed: 12801224] 
27. Canney DJ, Kung M, Kung HF. Amino- and amidotetrabenazine derivatives: Synthesis and evaluation as potential ligands for the vesicular monoamine transporter. Nucl Med Biol. 1995; 22:527-535. [PubMed: 7550031]

28. Lee LC, Vander BT, Sherman PS, Frey KA, Kilbourn MR. In vitro and in vivo studies of benzisoquinoline ligands for the brain synaptic vesicle monoamine transporter. J Med Chem. 1996; 39:191-196. [PubMed: 8568807]

29. Compere D, Marazano C, Das BC. Enantioselective access to lobelia alkaloids. J Org Chem. 1999; 64:4528-4532.

30. Zheng G, Dwoskin LP, Crooks PA. Indirect trapping of the retro-conjugate addition reaction intermediate involved in the epimerization of lobeline: Application to the synthesis of (-)sedamine. J Org Chem. 2004; 69:8514-8517. [PubMed: 15549833]

31. Ebnöther A. 48. Über die Mutarotation des Lobelins. Cis-trans-Isomere in der Reihe der Lobeliaalkaloide. Helv Chim Acta. 1958; 41:386-396.

32. Lee J, Freudenberg W. Piperidine derivatives. Part 1. Lobelan and related compounds. J Org Chem. 1944; 9:537-546.

33. Blickle FF, Zienty FB. Antispasmodics. IV. J Am Chem Soc. 1939; 61:774-776.

34. Stuhmer W, Elbrachter E. N-Substituierte bis(3,3'-phenylpropyl)amine. Arch Pharmacol. 1954; 287:139-142.

35. Daniels AJ, Reinhard JF Jr. Energy-driven uptake of the neurotoxin 1-methyl-4-phenylpyridine into chromaffin granules via the catecholamine transporter. J Biol Chem. 1988; 263:5034-5036. [PubMed: 3258595]

36. Darchen F, Scherman D, Henry JP. Characteristics of the transport of quaternary ammonium 1methyl-4-phenylpyridine by chromaffin granules. Biochem Pharmacol. 1988; 37:4381-4387. [PubMed: 3264161]

37. Del Zompo M, Piccardi MP, Quartu SRM, Gessa GL, Vaccari A. Selective uptake into synaptic dopamine vesicles: Possible involvement in MPTP neurotoxicity. Br J Pharm. 1993; 109:411-414.

38. Moriyama Y, Amakatsu K, Futai M. Uptake of the neurotoxin, 4-methylphenylpyridinium, into chromaffin granules and synaptic vesicles: A proton gradient drives its uptake through monoamine transporter. Arch Biochem Biophys. 1993; 305:271-277. [PubMed: 8373164] 
<smiles>[R2]c1ccc(C(=C)CN)cc1[R2]</smiles><smiles>CC[C@]1(O)C[C@H]2c3cc(OC)c(OC)cc3CCN2C[C@H](CC(C)C)[C@]1(C)CC(C)C</smiles>

Figure 1. 
<smiles>C[N+]1(C)[C@H](/C=C/c2ccccc2)CCC[C@H]1/C=C/c1ccccc1</smiles><smiles>C[N+]1(C)[C@H](/C=C/c2ccccc2)CCC[C@H]1/C=C/c1ccccc1</smiles><smiles>[Z10][N+]1(C)[C@H](CCc2ccccc2)CCC[C@H]1CCc1ccccc1</smiles><smiles>[R16][N+]1(C)[C@H](CCc2ccccc2)CCC[C@H]1CCc1ccccc1</smiles><smiles>CN[C@@H](CCCCCc1ccccc1)CCc1ccccc1</smiles><smiles>CN[C@H](CCCCCc1ccccc1)CCc1ccccc1</smiles>

25a<smiles>CN(C/C=C/c1ccccc1)C/C=C/c1ccccc1</smiles><smiles>CN(CCCc1ccccc1)CCCc1ccccc1</smiles>

26

27

Figure 2. 
(a)
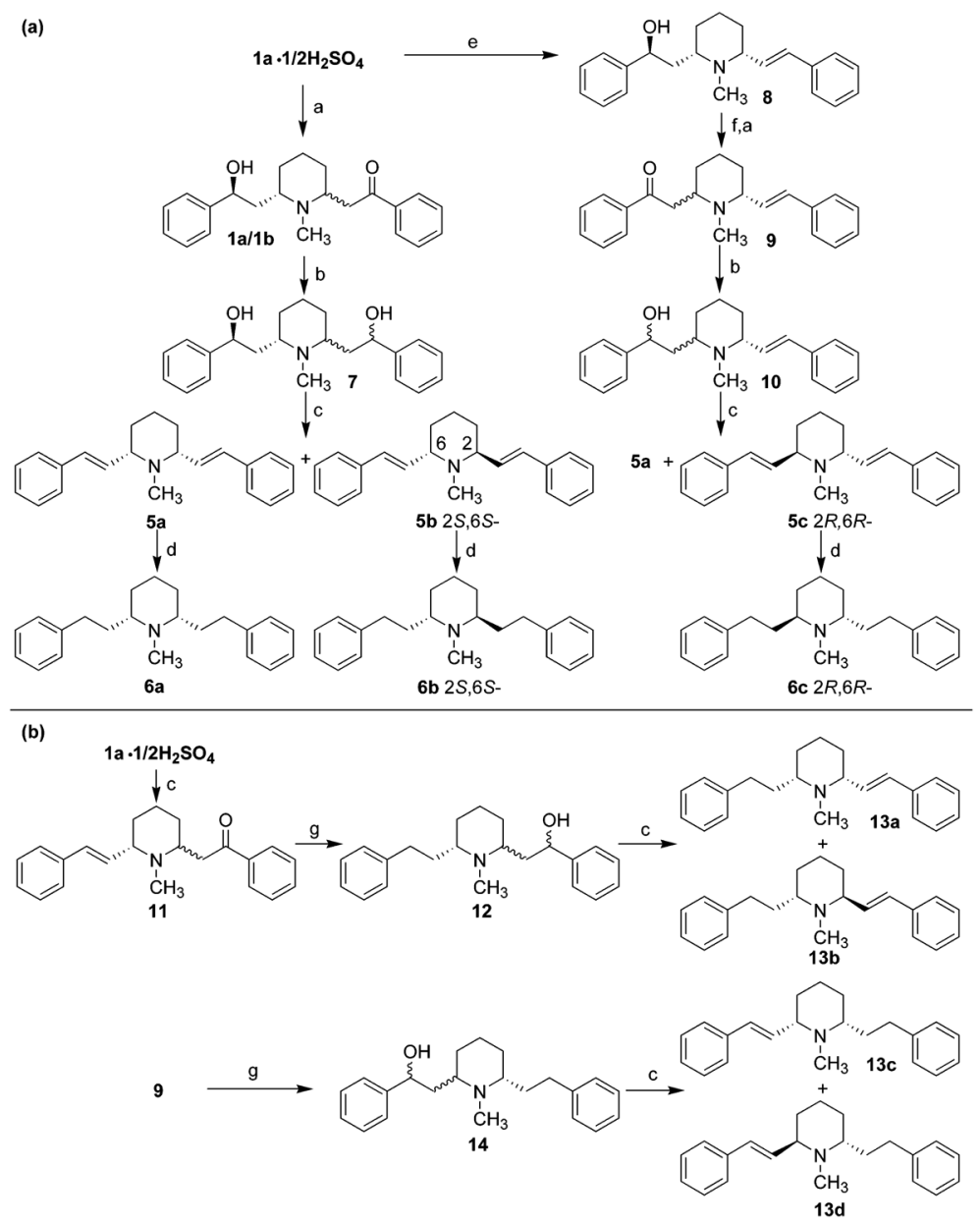

Scheme $1^{\text {a }}$

${ }^{a}$ Reagents and conditions: (a) $\mathrm{K}_{2} \mathrm{CO}_{3}$, $\mathrm{MeOH}$; (b) $\mathrm{NaBH}_{4}$, EtOH, rt; (c) $85 \% \mathrm{H}_{3} \mathrm{PO}_{4}, 60{ }^{\circ} \mathrm{C}$; (d) $\mathrm{H}_{2}, 10 \% \mathrm{Pd} / \mathrm{C}, \mathrm{MeOH}, 45 \mathrm{psi}$; (e) $\mathrm{Zn} / \mathrm{Hg}, \mathrm{HCl}$ (5\%), reflux; (f) $\mathrm{CrO}_{3}, \mathrm{H}_{2} \mathrm{SO}_{4}$, acetone, 0 ${ }^{\circ} \mathrm{C} ;(\mathrm{g}) \mathrm{H}_{2}, 10 \% \mathrm{Pd} / \mathrm{C}, 10 \% \mathrm{HOAc} / \mathrm{MeOH}, 45 \mathrm{psi}$. 
<smiles>CN1[C@@H](CCc2cccc(CCc3cccc(CCc4ccccc4)[n+]3C)c2)C=CC[C@@H]1CCc1ccccc1</smiles>
$\uparrow a, b$

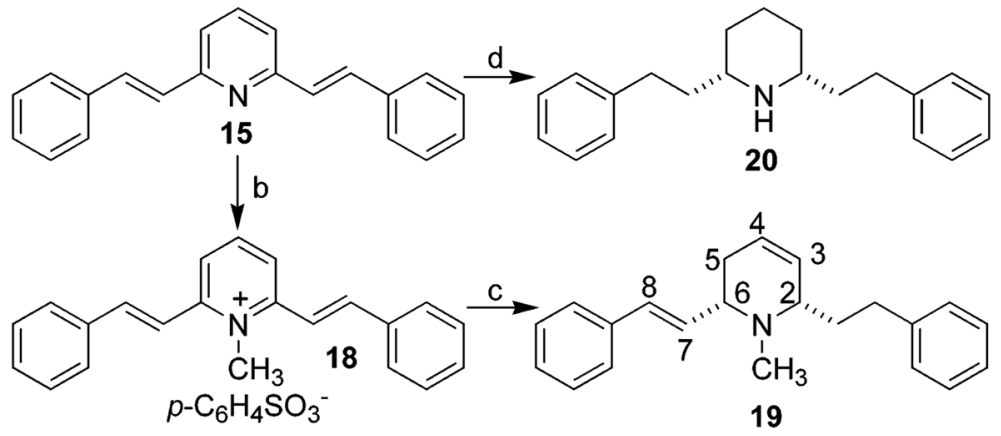

Scheme $2^{\mathrm{a}}$

${ }^{a}$ Reagents and conditions: (a) $\mathrm{H}_{2}, 10 \% \mathrm{Pd} / \mathrm{C}, \mathrm{MeOH}, 45 \mathrm{psi}$; (b) $p-\mathrm{C}_{6} \mathrm{H}_{4} \mathrm{SO}_{3} \mathrm{CH}_{3}, 170-180$ ${ }^{\circ} \mathrm{C}$; (c) $\mathrm{NaBH}_{4}$, EtOH, $0{ }^{\circ} \mathrm{C}$; (d) $\mathrm{H}_{2}, \mathrm{PtO}_{2}, \mathrm{HOAc}, 45$ psi. 


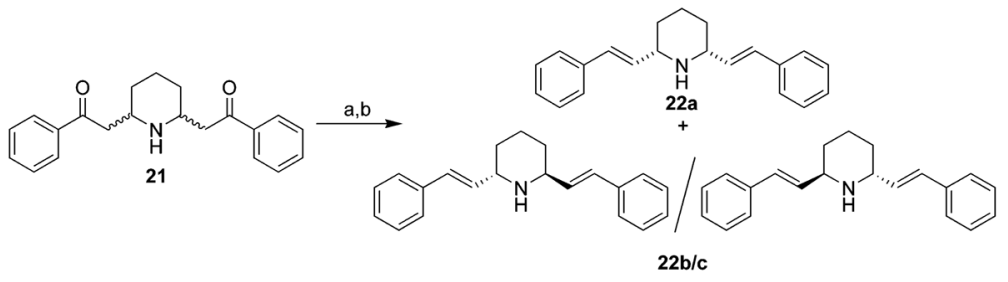

Scheme $3^{\mathbf{a}}$

${ }^{a}$ Reagents and conditions: (a) $\mathrm{NaBH}_{4}, \mathrm{EtOH}$, rt; (b) $85 \% \mathrm{H}_{3} \mathrm{PO}_{4}, 60{ }^{\circ} \mathrm{C}$. 

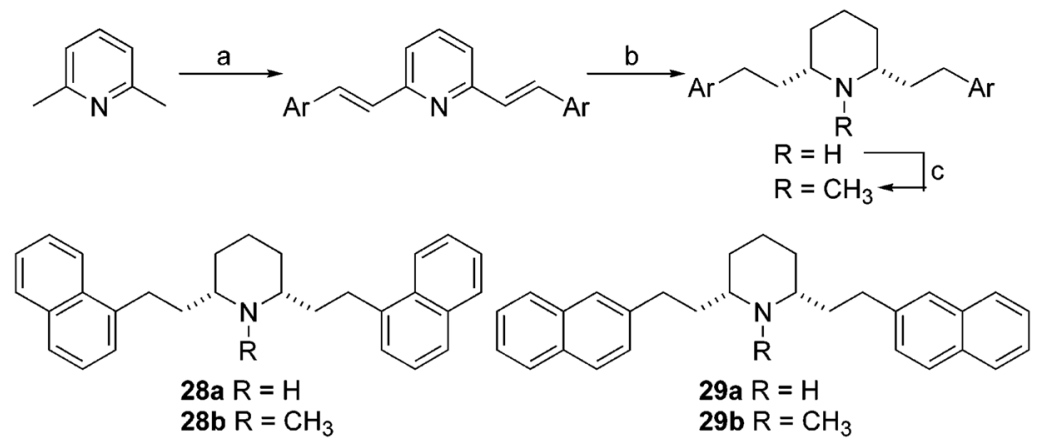

Scheme $4^{\mathbf{a}}$

${ }^{a}$ Reagents and conditions: (a) 1- or 2-naphthaldehyde, $\mathrm{Ac}_{2} \mathrm{O}$, reflux; (b) $\mathrm{H}_{2}, \mathrm{PtO}_{2}, 10 \%$ $\mathrm{HOAc} / \mathrm{MeOH}, 45 \mathrm{psi}$; (c) $\mathrm{NaCNBH}_{3},\left(\mathrm{CH}_{2} \mathrm{O}\right)_{n}, \mathrm{MeOH}$, rt. 


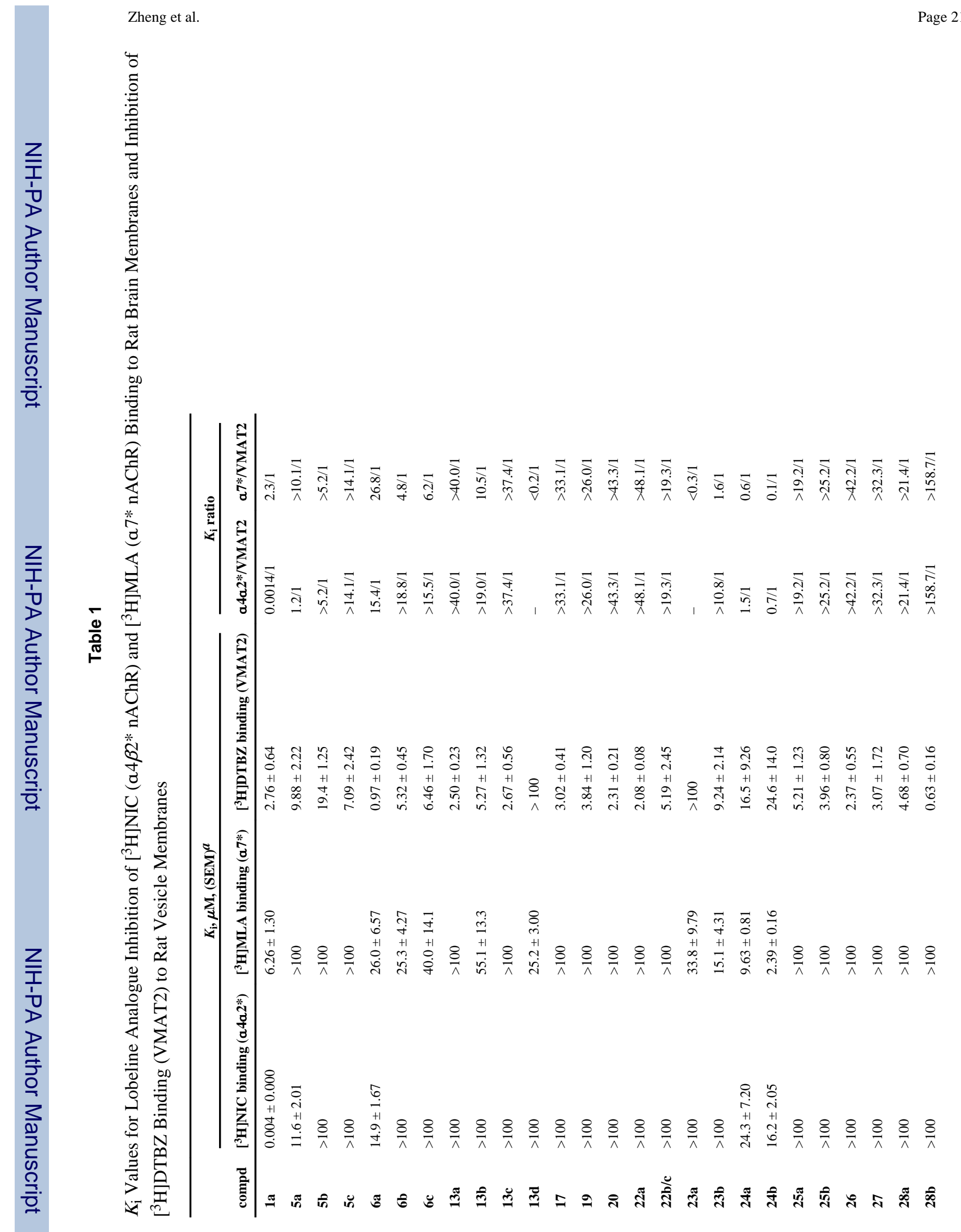

JMed Chem. Author manuscript; available in PMC 2013 April 05. 


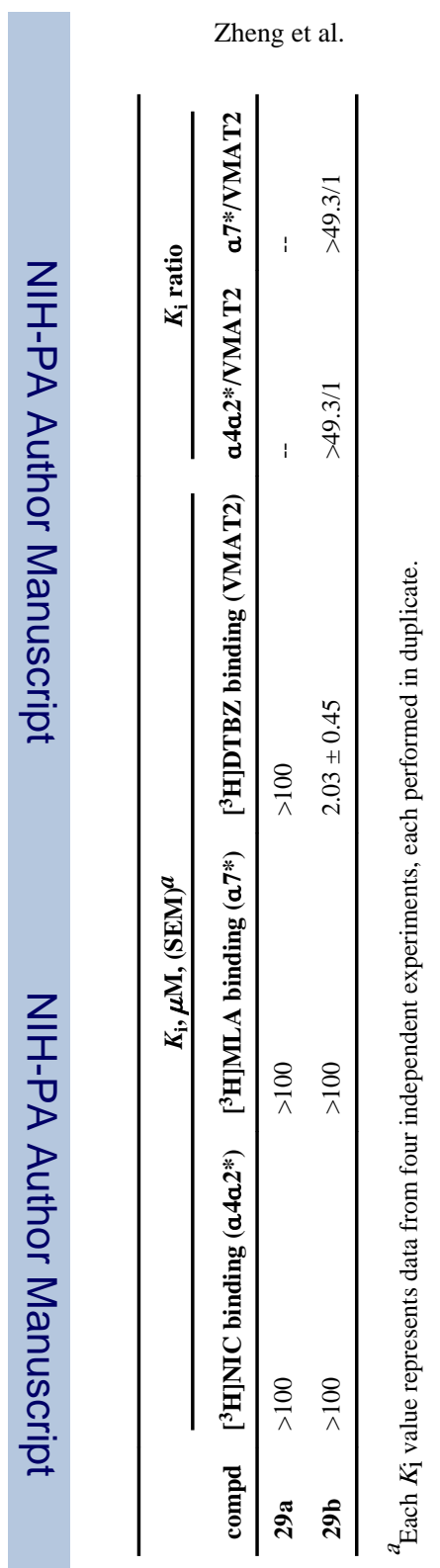

Page 22

$$
\text { I }
$$

